\title{
Target-Based Drug Discovery, ADMET Profiling and Bioactivity Studies of Antibiotics as Potential Inhibitors of SARS-CoV-2 Main Protease (Mpro)
}

Misbaudeen Abdul-Hammed ( $\square$ mabdul-hammed@lautech.edu.ng )

Ladoke Akintola University of Technology Faculty of Pure and Applied Science https://orcid.org/00000002-5453-5858

\section{Ibrahim Olaide Adedotun}

Ladoke Akintola University of Technology Faculty of Pure and Applied Science

\section{Victoria Adeola Falade}

Ladoke Akintola University of Technology Faculty of Pure and Applied Science

Adewusi John Adepoju

Ladoke Akintola University of Technology Faculty of Pure and Applied Science

\section{Sabitu Babatunde Olasupo}

NAFDAC: National Agency for Food and Drug Administration and Control

Modinat Wuraola Akinboade

Ladoke Akintola University of Technology Faculty of Pure and Applied Science

\section{Research Article}

Keywords: COVID-19, SARS-CoV-2 main protease, Conformer search, Molecular docking, Antibiotics, ADMET profiling

Posted Date: March 19th, 2021

DOl: https://doi.org/10.21203/rs.3.rs-310136/v1

License: (a) (1) This work is licensed under a Creative Commons Attribution 4.0 International License. Read Full License

Version of Record: A version of this preprint was published at VirusDisease on July 1st, 2021. See the published version at https://doi.org/10.1007/s13337-021-00717-z. 


\title{
Target-Based Drug Discovery, ADMET Profiling and Bioactivity Studies of Antibiotics as Potential Inhibitors of SARS-CoV-2 Main Protease ( $\mathbf{M}^{\text {pro }}$ )
}

Misbaudeen Abdul-Hammed ${ }^{1, *}$, Ibrahim Olaide Adedotun ${ }^{1}$, Victoria Adeola Falade ${ }^{1}$, Adewusi John Adepoju ${ }^{1}$, Sabitu Babatunde Olasupo ${ }^{3}$, and Modinat Wuraola Akinboade ${ }^{2}$

${ }^{1}$ Department of Pure and Applied Chemistry, Ladoke Akintola University of Technology, Ogbomoso, P.M.B. 4000, Nigeria

${ }^{2}$ Department of Biochemistry, Ladoke Akintola University of Technology, Ogbomoso, P.M.B. 4000, Nigeria

${ }^{3}$ National Agency for Food and Drug Administration and Control (NAFDAC), Abuja, Nigeria *Corresponding author: Abdul-Hammed, M., E-mail: mabdul-hammed@lautech.edu.ng: $+2348069151819$

\begin{abstract}
A recent outbreak of a new strain of Coronavirus (SARS-CoV-2) has become a global health burden, which has resulted in deaths. No proven drug has been found to effectively cure this fast-spreading infection, hence the need to explore old drugs with the known profile in tackling this pandemic. Computer-aided drug design approach involving virtual screening was used to obtain the binding scores and inhibiting efficiencies of previously known antibiotics against SARS-CoV-2 main protease $\left(\mathrm{M}^{\mathrm{pro}}\right)$. In silico pre-clinical studies which include Druglikeness, Bioactivity, and ADMET profiling were done using Molinspiration online tool and ADMET SAR2 webserver respectively, and the results were compared with those of drugs currently involved in clinical trials in the ongoing pandemic. Although antibiotics have been speculated to be of no use in the treatment of viral infections, literature has emerged lately to reveal antiviral potential and immune-boosting ability of antibiotics. This study identified Tarivid and Ciprofloxacin with binding affinities of -8.3 and $-8.1 \mathrm{kcal} / \mathrm{mol}$, respectively as significant inhibitors of SARS-CoV-2 $\left(\mathrm{M}^{\mathrm{pro}}\right)$ with better pharmacokinetics, drug-likeness and oral bioavailabity, bioactivity properties, ADMET properties and inhibitory strength compared to Remdesivir $(-7.6 \mathrm{kcal} / \mathrm{mol})$ and Azithromycin $(-6.3 \mathrm{kcal} / \mathrm{mol})$. These observations will provide insight for further research (clinical trial) in the cure and management of COVID-19.
\end{abstract}

Keywords: COVID-19, SARS-CoV-2 main protease, Conformer search, Molecular docking, Antibiotics, ADMET profiling. 


\section{Introduction}

The outbreak of a respiratory tract infection identified in a cluster of pneumonia patients in Wuhan China has become a global health challenge that cut across all continents of the world [1]. The previously unknown causative virus was later identified as novel CoV-19 by the world health organization [2] and since it has symptoms close to Severe Acute Respiratory Syndrome Coronavirus, hence the name SARS-CoV-2. According to John Hopkins Coronavirus Resource Centre (https://coronavirus.jhu.edu/map.html), the number of confirmed and death cases are increasing globally on daily basis, with more than 112,305,539 confirmed and 2,486,641 death cases reported so far. The disease was referred to as pandemic rather than epidemic because of the rate and speed of transmission. These figures revealed that this SARS-CoV-2 is a lifethreatening disease that has become a major health concern worldwide. Symptoms include cough, fever, short breathing, chest pain, sore throat, and lower respiratory tract symptoms [3].

Over the years, antibiotics have been a strong resort in a bid to cure the infection pathway and have tremendously saved several millions of lives [4]. Administration of these antibiotics recorded great success both in the developed and developing world due to low morbidity and mortality rate [5]. Despite its efficacy as an antimicrobial agent, antibiotics have been speculated to either be of no use or inappropriate in the treatment of viral infections including respiratory tract infections, except for pneumonia which regardless of its etiology is still treated with antibiotics [6,7]. Hence its place in the treatment/management of SARS-CoV-2 (COVID-19) is questionable.

More recently, literature has emerged that offers contradictory findings of the inappropriate use of antibiotics in viral infections; In 2016, an experiment undertaken by Karst pointed out that there exists a relationship between commensal bacteria and viruses, and that this relationship enhances and facilitate binding of the virus to the host cell, he, however, revealed that the depletion of commensal bacterial with antibiotics reduced viral load and replication in the host cell [8]. Also, Gopinath and his team reported that topical administration of aminoglycoside antibiotics reduced viral replication and also increased host resistance to viral infections like influenza A, Zika virus, and herpes virus without depletion of commensal bacteria [9]. Similarly, topical administration of neomycin (a nontoxic vagina aminoglycoside antibiotics)

on immunized rats induced with the herpes virus, enhance the immune response of the host and hence conferred protection against the virus, noting that there was no protection in the absence of 
immunization vaccine [10],this research complement the findings of Miller, that Childhood bacillus Calmette-Guerin (BCG) vaccination reduced the number of reported cases, morbidity, and mortality in the ongoing COVID-19 pandemic [11]. In another research, azithromycin, a macrolide antibiotic was found to inhibit replication of the Zika virus [12] as well as the reduction in viral load and inactivation of endocartic activity of newly budded progeny in human influenza virus [13]. Collectively, these studies highlight the unexpected antiviral potential of antibiotics.

As the struggle in finding lasting solution to this world threat (COVID-19) continues, many commercial drugs (antibiotics \& antiviral) and vaccines have been used and subjected to randomized clinical trials. Also, measures have been put in place to reduce the rate of transmission via social distancing, regular hand washing as well as the use of personal protective equipment like hand gloves and nose mask. However, repositioning old drugs whose safety profile, pharmacokinetics, side effects, drug interactions, and optimal dosage level are well known is an efficient tool in drug discovery [14,15] especially with this fast-spreading pandemic.

Among the candidate drugs already considered for repositioning/repurposing against SARS-CoV-2 are chloroquine, azithromycin, remdesivir, lopinavir, favipiravir, ritonavir, ivermectin, and ruxolitinib. A considerable amount of literature has been published on the effect of chloroquine on SARS-CoV-2 [16]; these studies provide evidence for its effectiveness against SARS-CoV-2virus replication. Clinical trials involving the use of azithromycin has also been reported [15]. In the same vein, remdesivir, favipiravir, and ivermectin, previously shown to possess broad-spectrum antiviral activity inhibit the SARS-CoV-2 virus in vitro [17,18]. Ruxolitnib, lopinavir, and ritonavir (clinicaltrials.gov/ct2/show/NCT04334044) have been undergoing trials in the management of SARS-CoV-2 virus [19].

Nevertheless, as the world is witnessing the second wave of the pandemic despite the available vaccines, the struggle of total apprehension of this critical situation of the world remains a major concern of drug design experts and researchers, therefore, the present study is aimed at investigating the inhibitory potential of some selected antibiotics against the novel SARS-CoV-2 main protease ( $\mathrm{M}^{\text {pro }}$ ) via target-based drug discovery approach (virtual screening), drug-likeness analysis, oral-bioavailability studies, ADMET profiling, and bioactivity studies. 


\section{Materials and Methods}

\section{Preparation of Ligands}

In this study, sixteen commercial antibiotics were used as ligands, while two clinically drugs (Remdesivir and Azithromycin) whose randomized clinical trials as probable inhibitors of SARS-CoV-2 main protease have been established were used as standards. The 3D structures of the ligands and standards were obtained from the PubChem database (https://pubchem.ncbi.nlm.nih.gov). Conformational search was performed using Spartan 14 Conformer Distribution with Molecular Mechanics/MMFF, and the most stable conformers were chosen and optimized. Optimization was carried out on Spartan 14' software using density functional theory (DFT) method with the B3LYP functional and the 6-31+G (d) as the basis set.

\section{Preparation of Target Receptor}

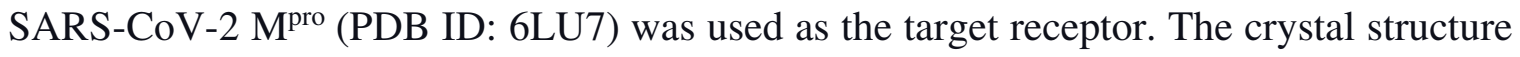
was retrieved from the protein data bank (RCSB) (http://www.rcsb.org/pdb). SARS-CoV-2(M ${ }^{\text {pro }}$ ) [20] is an important protease that mediates replication and transcription of the virus and thus the main target of potential inhibitors. The co-crystallized molecules were removed to avoid any unwanted molecular interactions with the target receptor during virtual screening exercise using

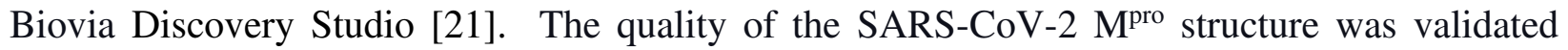
using the Ramachandran plot (Fig.1). The grid box (binding pocket) of the native ligand inhibitor used with the target receptor was employed as a basis to define the binding pocket for the $\mathrm{X}, \mathrm{Y}$, and $\mathrm{Z}$ coordinate as $-26.284,12.603$ and 58.96 respectively and the whole protease (target receptor) was enclosed in the grid. 


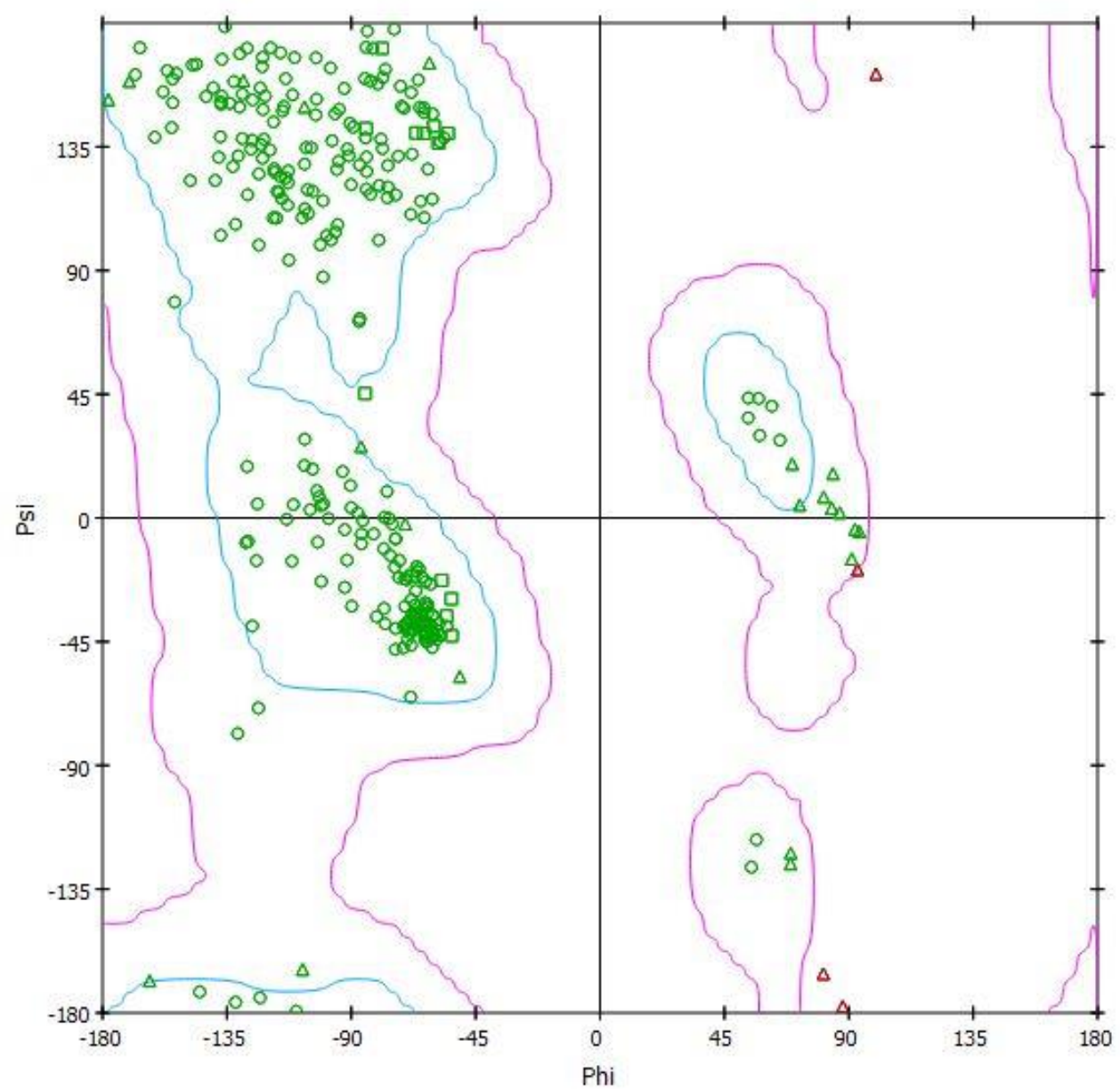

Fig.1 The Ramachandran plot of SARS-CoV-2 M Mro $^{\text {(6LU7) }}$

\section{Determination of (6LU7) Mpro Active Sites}

Computed Atlas for Surface Topography of Proteins (CASTp) (http://sts.bioe.uic.edu/castp/index.html?2011) [22] and Biovia Discovery Studio (2019) were used to determine binding pocket, amino acids and all ligands interactions in the active site of SARS-CoV-2M pro. The result obtained was validated using experimental results reported for SARS-CoV-2M $\mathrm{M}^{\text {pro }}$ in complex with N3 native ligand [23]. 


\section{Molecular Docking Simulation}

Docking simulations of the optimized most stable conformers (ligands and standards) against the target receptor (SARS-CoV-2 $\mathrm{M}^{\text {pro }}$ ) were done using Autodock (MGL tool- 1.5.6) and AutodockVina [24]. The inhibiting abilities of the ligands and standards against the target receptor using their respective binding affinities ( $\mathrm{kcal} / \mathrm{mol}$ ) were assessed using equation 1 , while other molecular interactions occurred during the simulation were viewed using

Biovia-2019 Discovery Studio [21].

$K_{i}=10^{(B . E . / 1.366)} \ldots$... (1) ( $K_{i}$ is the inhibition constant in $\mu M$ and B.E. is the binding energy in kcal/mol).

\section{Assessment of Pharmacokinetic Properties}

ADMET SAR2 [25] was used to predict the absorption, distribution, and metabolism and toxicity properties of the selected compounds. SwissADME web server was used to investigate the oral bioavailability properties of the compounds while important features related to druglikeness of the selected compounds were evaluated using Molinspiration online tool (http://molinspiration.com/).

\section{Results and discussion}

\section{Structural and Active site Analysis of SARS-CoV-2Mpro (PDB ID: 6LU7)}

SARS-CoV-2 main protease (PDB ID: 6LU7) is an X-ray crystallographic structure containing 306 amino acids residues in complex with an inhibitor N3-(N-[(5-Methylisoxazol-3Yl)Carbonyl]Alanyl-L-Valyl-N 1 -((1r,2z)-4-(Benzyloxy)-4-Oxo-1-\{ [(3r)-2-Oxopyrrolidin-3Y1]Methyl\}But-2-Enyl)-L-Leucinamide). Its constituent's secondary structures include 23\%, $31 \%, 45 \%$ and $28 \% \alpha$-helix, $\beta$-sheets, Coil and Turns respectively. As revealed in the X-ray diffraction study, the protease has a resolution of $2.16 \AA$ with crystal dimension of $\mathrm{a}=97.93 \AA$, b $=79.48 \AA$ and $\mathrm{c}=51.08 \AA$ and angles $\alpha(900), \beta$ (114.550) and $\gamma(900)$ respectively. The Total Accessible Surface Area (ASA) of the protease is 14043.1( $\AA$ ) 2 and the R-values (free, work, and observed) are $0.235,0.202$, and 0.204 respectively. The main protease has three domains 
which are: Domain I (residues 8-110), Domain II (residues 102-184), and Domain III (residues 185-200) [23]. The active site of SARS-CoV-2 main protease is situated in the cleft between Domain I and II and contains a Cys-His catalytic dyad [23]. The structure and active sites of SARS-CoV-2 main protease (PDB ID: 6LU7) in complex with N3 ligand are shown in Table 1.

\section{Table 1}

The structure and active site of SARS-CoV-2 main protease $\left(\mathrm{M}^{\mathrm{pro}}\right)$ in complex with N3 native ligand

\begin{tabular}{lll}
\hline PDB ID & Macromolecule and Native Ligand & Active site amino acids \\
\hline 6LU7 & $\begin{array}{l}\text { Thr24, Thr25, Thr26, His41, } \\
\text { Met49, Tyr54, Phe140, Leu141, } \\
\text { Asn142, Gly143, Ser144, Cys145, } \\
\text { His163, His164, Met165, Glu166, } \\
\text { Leu176, Pro168, His172, Asp187, } \\
\text { Arg188, Gln189, Thr190, Ala191, } \\
\text { Gln192 }\end{array}$
\end{tabular}

\section{Molecular Docking Analysis}

Recent developments in drug discovery/design have led to a renewed interest in computational strategies, as this affords faster and cheaper screening of molecules for biological and chemical interactions [26]. Molecular docking is an important tool in computational drug discovery that provide predictive information on the binding of small molecules to target receptor [27]. The molecular docking approach has found wide application because it offers predictions with a higher degree of accuracy of binding affinities, intermolecular interaction, and conformations of ligand's molecule at receptor's binding sites [26-28]. The docking scores of the ligands and standards against SARS-CoV-2 M From the results, a good number of ligands displayed activity comparable to those of standards. Binding affinities for the standards ranges between $-7.6 \mathrm{kcal} / \mathrm{mol}$ (Remdesivir) and $-6.3 \mathrm{kcal} / \mathrm{mol}$ (Azithromycin) while those of the ligands were between $-8.3 \mathrm{kcal} / \mathrm{mol}$ and $-4.9 \mathrm{kcal} / \mathrm{mol}$. Overall, tarivid with binding affinity $-8.3 \mathrm{kcal} / \mathrm{mol}$ had the most outstanding inhibitory activity, 
amino acids involved in its hydrogen bond interaction with receptor molecules are Glu166, Tyr54, Asp187, and Met49, while electrostatic/hydrophobic interactions include Phe140, Asn142, His41, Met165, Arg188. It is interesting to note that tarivid (ofloxacin) and ciprofloxacin displayed better inhibitory activity against SARS-CoV-2virus Mpro (as shown by the binding affinity and inhibition constant) than remdesivir even though more recovery rate had recently been recorded in the use of the later but not without some fatality and side effects (https://www.nature.com/articles/d41586-020-01295-8). The high binding affinity recorded, could be attributed to the multiple hydrogen, electrostatic and hydrophobic bonds involved in binding to amino acids at the active site of SARS-CoV-2 $\mathrm{M}^{\text {pro }}$. Tetracycline also demonstrated inhibitory activity almost equal in strength to remdesivir against SARS-CoV-2 while doxycycline and Penicillin $\mathrm{G}$ inhibited the virus much better than Azithromycin.

Table 2 Docking scoring, binding sites, hydrogen bond distances and the inhibition constants of the interaction of selected antibiotics and standard drugs with SARS-CoV-2(M ${ }^{\text {pro }}$ ) (PDB ID: 6LU7), a prominent target receptor of inhibitors of the Severe Acute Respiratory Syndrome Coronavirus (SARS-CoV-2).

\begin{tabular}{|c|c|c|c|c|}
\hline Ligands & $\begin{array}{c}\text { Binding } \\
\text { Affinity }(\Delta G) \text {, } \\
\text { kcal } / \mathbf{m o l}\end{array}$ & $\begin{array}{c}\text { 6LU7 Receptor } \\
\text { amino acids forming H-bond with } \\
\text { ligands }(\mathbf{H}-\text { Bond Distance, } \stackrel{\AA}{\mathbf{A}})\end{array}$ & $\begin{array}{c}\text { Electrostatic/ } \\
\text { Hydrophobic } \\
\text { Interactions involved }\end{array}$ & $\begin{array}{r}\text { Inhibition } \\
\text { Constant } \\
\left(\mathbf{K}_{\mathrm{i}}\right), \boldsymbol{\mu M}\end{array}$ \\
\hline Tarivid & -8.3 & $\begin{array}{c}\text { Glu166 (2.0 }), \operatorname{Tyr} 54(2.8 \AA) \\
\text { Asp187 }(3.0 \AA), \operatorname{Met} 49(3.3 \AA) \\
\text { Glu166 (3.6 } \AA)\end{array}$ & $\begin{array}{c}\text { Phe140, Asn142, His41, } \\
\text { Met165, Arg188 }\end{array}$ & 0.83 \\
\hline Ciprofloxacin & -8.1 & $\begin{array}{c}\text { Phe140 (2.5 ̊), Tyr54 (2.8 ̊) } \\
\text { Asp187 (3.1 }), \operatorname{Gln} 189(3.1 \AA)\end{array}$ & $\begin{array}{c}\text { Met49, Met165, } \\
\text { His41,Cys145, } \\
\text { Asn142,Leu141 }\end{array}$ & 1.16 \\
\hline Remdesivir & -7.6 & 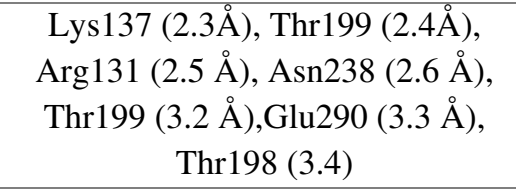 & $\begin{array}{l}\text { Leu286, Asp289, } \\
\text { Asp197 }\end{array}$ & 2.70 \\
\hline Tetracycline & -7.5 & $\begin{array}{c}\text { Cys145 }(2.1 \AA), \operatorname{Thr} 26(2.4 \AA), \\
\text { Thr26 (2.6 }), \operatorname{Ser} 144(2.8 \AA), \\
\operatorname{Thr} 26(2.9 \AA), \operatorname{Thr} 26(3.1 \AA), \\
\text { Leu141 (3.1 }), \operatorname{Thr} 24(3.1 \AA), \\
\text { Thr24 (3.1 })\end{array}$ & Gly143 & 3.2 \\
\hline Doxycycline & -7.0 & $\begin{array}{l}\text { Thr190 (2.2 ̊), Glu166 (3.0 ̊), } \\
\text { Gln189 (3.0 ̊), His164 (3.0 ̊) }\end{array}$ & $\begin{array}{l}\text { Leu167, Pro168, } \\
\text { Cys145 }\end{array}$ & 7.43 \\
\hline Penicillin G & -7.0 & $\begin{array}{c}\operatorname{Gln} 110(2.1 \AA), \operatorname{Arg} 105(3.0 \AA) \\
\operatorname{Thr} 111(3.3 \AA)\end{array}$ & Val104, Phe294 & 7.43 \\
\hline Pefloxacin & -6.9 & $\begin{array}{l}\text { Gly143 }(2.2 \AA), \operatorname{Ser} 144(2.4 \AA), \\
\text { Cys145 }(2.5 \AA), \operatorname{His} 163(2.8 \AA),\end{array}$ & Glu166, Thr190 & 8.80 \\
\hline
\end{tabular}




\begin{tabular}{|c|c|c|c|c|}
\hline & & Leu141 (2.9 $\AA), \operatorname{Asn} 142(3.5 \AA)$ & & \\
\hline Amocixillin & -6.8 & $\begin{array}{c}\text { Leu272 }(3.0 \AA), \text { Leu271 }(3.0 \AA), \\
\text { Asp289 }(3.0 \AA), \operatorname{Thr} 199(3.3 \AA), \\
\operatorname{Arg} 131(2.6 \AA)\end{array}$ & Leu286, Tyr237 & 10.41 \\
\hline Zinacef & -6.6 & 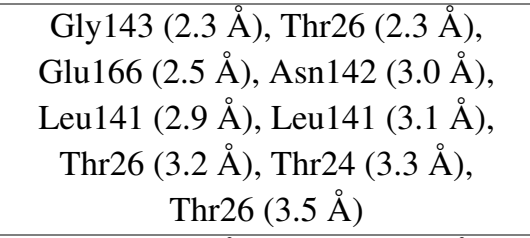 & His41 & 14.59 \\
\hline Nitrofuratoin & -6.5 & 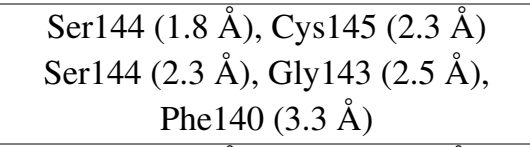 & His41 & 17.27 \\
\hline Sulfamethoxazole & -6.4 & $\begin{array}{c}\text { Gln110 }(2.0 \AA), \operatorname{Thr} 111(2.1 \AA), \\
\operatorname{Asp} 153(2.5 \AA), \operatorname{Asn} 151(3.1 \AA), \\
\text { Thr111 (3.4 } \AA)\end{array}$ & Val104, Phe294 & 20.45 \\
\hline Penicillin V & -6.4 & $\begin{array}{c}\text { Gly143 }(2.2 \AA), T h r 26(2.8 \AA) \\
\text { Gln189 }(3.3 \AA)\end{array}$ & $\begin{array}{c}\text { Met165, His164, His41, } \\
\text { Met49 }\end{array}$ & 20.45 \\
\hline Azithromycin & -6.3 & $\begin{array}{c}\text { Asp197 }(3.0 \AA), \text { Tyr237 (3.0 ̊), } \\
\text { Asp289 (3.5 ̊) }\end{array}$ & $\begin{array}{l}\text { Met276, Leu286, } \\
\text { Leu287, Tyr239 }\end{array}$ & 24.20 \\
\hline Gentamycin & -6.2 & 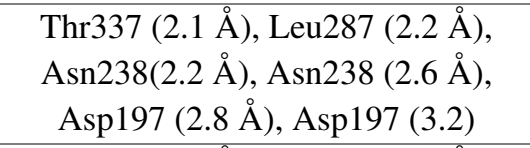 & Nil & 28.65 \\
\hline Trimethoprim & -6.2 & $\begin{array}{c}\text { His163 (2.1 } \AA), A s n 142(2.2 \AA) \\
\text { Glu166 (2.4 } \AA), \text { Phe140 (2.5) }\end{array}$ & $\begin{array}{l}\text { Leu141, Met165, } \\
\text { Cys145, His41 }\end{array}$ & 28.65 \\
\hline Chloroquine & -5.5 & His164 & Asn142, His41, Met165 & 93.34 \\
\hline Clavulanic Acid & -5.4 & 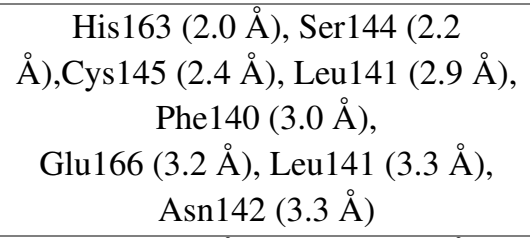 & Met165 & 110.50 \\
\hline Fosfomycin & -4.9 & $\begin{array}{l}\text { Thr111 (1.9 } \AA), \operatorname{Gln} 110(2.1 \AA), \\
\operatorname{Gln} 110(2.4 \AA), T h r 111(2.8 \AA), \\
\text { Asn151(2.9 } \AA), \operatorname{Thr} 111(3.1 \AA)\end{array}$ & Phe294, Asp295 & 256.86 \\
\hline
\end{tabular}

More recently, literature has emerged on the potential of tetracycline in the treatment of COVID-19 and this has further supported findings from this study [29]. Other ligands used in this study displayed notable inhibition better than azithromycin. The inhibition potential of the drugs as ranked by the binding affinity (Fig.2) and inhibition constant are as shown below.

Tarivid $>$ Ciprofloxacin $>$ Remdesivir $>$ Tetracycline $>$ Doxycycline $=$ Penicillin $G>$ Pefloxacin > Amoxicillin >Zinacef>Nitrofuratoin> Sulfamethoxazole > Penicillin V >Azithromycin > Trimethoprim $=$ Gentamycin $>$ Chloroquine $>$ ClauvanilicAcid $>$ Fosfomycin .

This study furnishes tarivid, ciprofloxacin, tetracycline, and doxycycline (Fig. 3 and 4) as significant potential inhibitors of SARS-CoV-2 as compared to remdesivir and zithromycin. Tarivid (ofloxacin) and ciprofloxacin are floroquinolones, with good oral and pharmacokinetic 
properties, they demonstrated broad-spectrum activity against bacterial infections including lower and upper respiratory tract infections (RTI) [30], the efficacy of ceftazidime and ciprofloxacin in clinical trials involving RTI patients has been reported in the literature, although, ceftazidime was not as effective as ciprofloxacin [31].

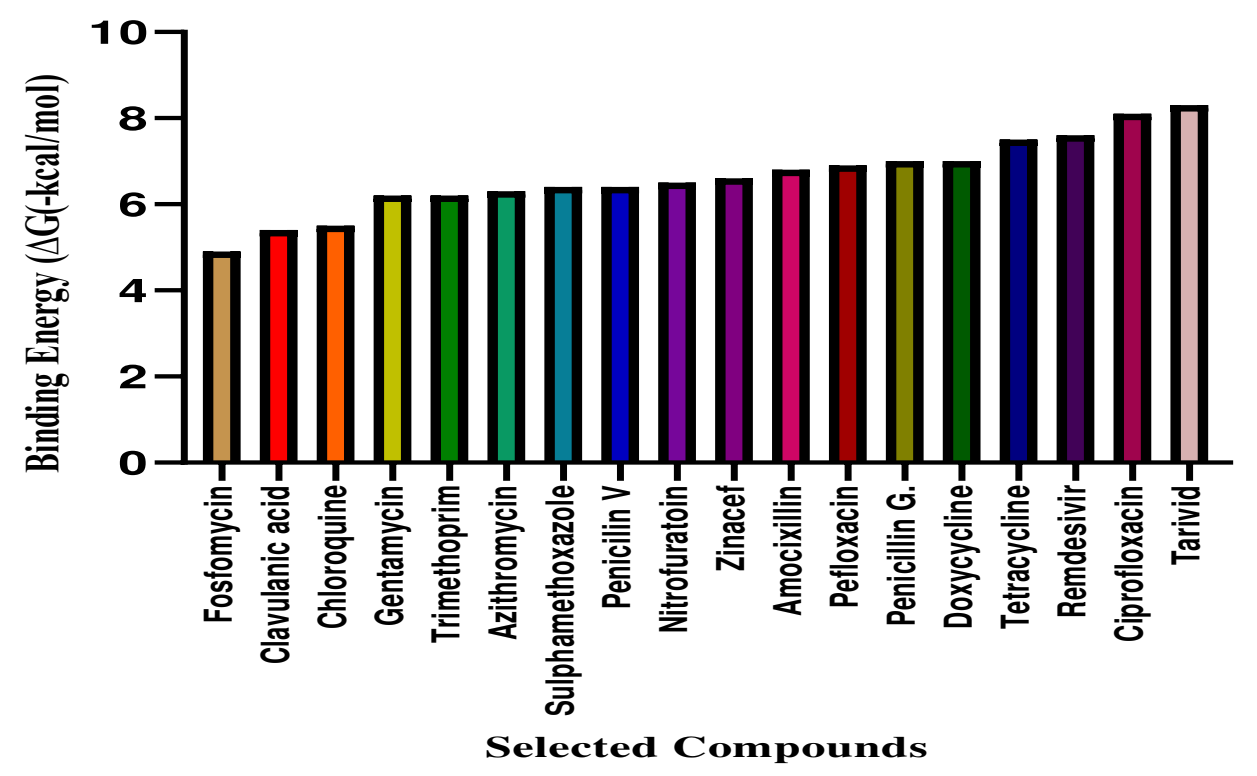

Fig. 2 The bar chart showing the molecular docking scores between $\mathrm{M}^{\text {pro }}$ (6LU7) and selected drug candidate compounds. (The value for binding energy $(\Delta \mathrm{G})$ is indicated in minus $\mathrm{kcal} / \mathrm{mol}$ )

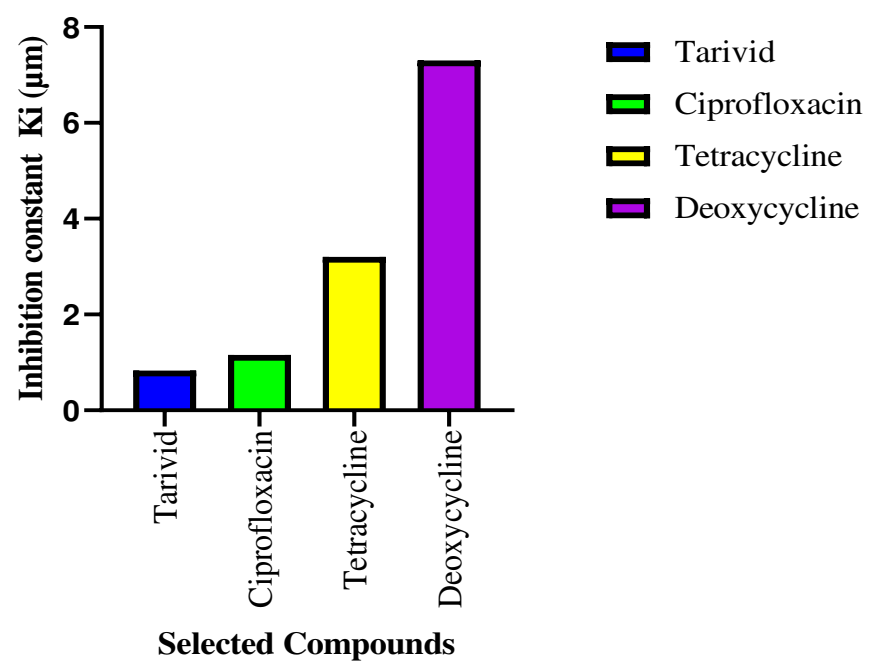

Fig. 3 The bar chart showing the selected Antibiotics as significant potential inhibitor of SARSCoV-2M $\mathrm{M}^{\text {Pro }}$ 
<smiles>CC1COc2c(N3CCN(C)CC3)c(F)cc3c(=O)c(C(=O)O)cn1c23</smiles><smiles>CN(C)C1C(=O)C(C(N)=O)=C(O)C2(O)C(=O)C3=C(O)c4c(O)cccc4C(C)(O)C3CC12</smiles><smiles>O=C(O)c1cn(C2CC2)c2cc(N3CCNCC3)c(F)cc2c1=O</smiles>

B

D

Fig. 4 The Structures of Selected Compounds (a) Tarivid (b) Ciprofloxacin (c) Tetracycline (d) Doxycycline

\section{Drug-likeness and Oral Bioavailability Analysis of the selected compounds and Standards}

Analysis of the pharmacokinetic properties of potential drug candidates is very essential in the early stage of drug discovery. According to Lipinski and his team, drug-like compounds must obey the rule of five (RO5) i.e. molecular weight $(\mathrm{MW}) \leq 500 \mathrm{Da}$, number of hydrogen bond donor (HBD's) $\leq 5$, number of hydrogen bond acceptor (HBAs) $\leq 10$ and octanol-water partition coefficient $(\log \mathrm{P}) \leq 5$ and no more than one violation is allowed [32]. As shown in Table 3, the HA, MW, HBD, HBA, and Log P values of all the selected compounds are within the acceptable range as stated in the RO5 and no compound violate more than one rule, whereas, the two standard drugs used (Remdesivir, S-1, and Azithromycin, S-2) have two violations respectively.

The oral bioavailability and other physicochemical properties of the selected compounds and standards obtained using the SwissADME web tool are shown in Table 4. The 
bioavailability radar (Fig. 5) gives a swift catch sight of the important physicochemical properties and drug-likeness of the selected compounds and standards [33]. As shown in (Fig. 5), the coloured portion (Pink) shows the most desirable area for each of the bioavailability properties (LIPO, SIZE, INSOLU, POLAR, INSATU, and FLEX). The octanol-water partition coefficient (XLOGP3) (Table 4) was used to determine the LIPO (Lipophilicity) of the selected compounds and standards. Surprisingly, all the selected compounds and standards were in the coloured region and fall within the LIPO recommended range of -0.7 to +5.0. According to Lipinski rule of five (RO5), the SIZE (Molecular Weight) of a good drug candidate is expected not to be more than 500gmol-1, of which of all selected compounds (C-1 to C-4) obey except the two standards $(\mathrm{S}-1=602.58, \mathrm{~S}-2=748.98)$. The INSOLU (insolubility) requirement of the selected compounds and standards as depicted in their ESOL (Log S) and ESOL Class revealed that $\mathrm{C}-1, \mathrm{C}-2$, and $\mathrm{C}-3$ are very soluble, while $\mathrm{C}-4$ is soluble and S-1 and S-2 are moderately soluble and insoluble respectively. The Total Polarity Surface Area (TPSA) whose recommended value is between the range of 20 and $130 \AA 2$ was used to examine the POLAR (polarity) of the selected compounds and standards. As shown in Table 4 and Fig. 5, only C-1 and C-2 fall within the optimal range while others fell apart. The fraction of carbon Sp3 (CSP3) which is expected to be the range of 0.25 and 1 and the number of the rotatable bond which should not exceed nine are used to determine the INSOLU (insolubility) and FLEX (flexibility) of the selected compounds are standards. Interestingly, all the selected compounds fall within the INSOLU recommended range of values while only Remdesivir (S-1) disobey the FLEX requirement. Put together, Tarivid (C-1) and Ciprofloxacin (C-2) have the best oral bioavailability since all their physicochemical properties fall within the optimal coloured (pink) region. 
Table 3 Drug-likeness Evaluation of the Significant Antibiotics and standards using Molinspiration online tool

\begin{tabular}{ccccccc}
\hline Compounds & $\begin{array}{c}\text { Heavy } \\
\text { atoms } \\
\text { (HA) }\end{array}$ & $\begin{array}{c}\text { Molecular } \\
\text { weight (MW) }\end{array}$ & $\begin{array}{c}\text { RO5 } \\
\text { Violations }\end{array}$ & $\begin{array}{c}\text { Hydrogen bond } \\
\text { donor (HBD) }\end{array}$ & $\begin{array}{c}\text { Hydrogen } \\
\text { bond acceptor } \\
\text { (HBA) }\end{array}$ & $\begin{array}{c}\text { miLog } \\
\mathbf{P}\end{array}$ \\
\hline C-1 & 26 & 361.37 & 0 & 1 & 7 & -0.26 \\
\hline C-2 & 24 & 331.35 & 0 & 2 & 6 & -0.70 \\
\hline C-3 & 32 & 444.44 & 1 & 7 & 10 & -0.24 \\
\hline C-4 & 32 & 444.44 & 1 & 7 & 10 & -0.43 \\
\hline S-1 & 42 & 602.59 & 2 & 5 & 14 & 2.82 \\
\hline S-2 & 52 & 749.00 & 2 & 5 & 14 & 2.73 \\
\hline
\end{tabular}

Table 4 Oral Bioavailability Analysis of the selected compounds and standards using SwissADME

\begin{tabular}{|c|c|c|c|c|c|c|}
\hline Ligand & C-1 & $\mathrm{C}-2$ & $\mathrm{C}-3$ & C-4 & S-1 & S-2 \\
\hline Formula & $\underset{4}{\mathrm{C}_{18} \mathrm{H}_{20} \mathrm{FN}_{3} \mathrm{O}}$ & $\mathrm{C}_{17} \mathrm{H}_{18} \mathrm{FN}_{3} \mathrm{O}$ & $\begin{array}{c}\mathrm{C}_{22} \mathrm{H}_{24} \mathrm{~N}_{2} \mathrm{O} \\
8\end{array}$ & $\begin{array}{c}\mathrm{C}_{22} \mathrm{H}_{24} \mathrm{~N}_{2} \mathrm{O} \\
8\end{array}$ & $\begin{array}{c}\mathrm{C}_{27} \mathrm{H}_{35} \mathrm{~N}_{6} \mathrm{O}_{8} \\
P\end{array}$ & $\begin{array}{c}\mathrm{C}_{38} \mathrm{H}_{72} \mathrm{~N}_{2} \mathrm{O}_{1} \\
2\end{array}$ \\
\hline VINA Score & -8.3 & -8.1 & -7.5 & -7.0 & -7.6 & -6.3 \\
\hline Mass & 361.37 & 331.34 & 444.43 & 444.43 & 602.58 & 748.98 \\
\hline TPSA & 75.01 & 74.57 & 181.62 & 181.62 & 213.36 & 180.08 \\
\hline $\begin{array}{l}\text { \#Rotatable } \\
\text { bonds }\end{array}$ & 2 & 3 & 2 & 2 & 14 & 7 \\
\hline XLOGP3 & -0.39 & -1.08 & -1.30 & 0.54 & 1.91 & 4.02 \\
\hline WLOGP & 1.2 & 1.18 & -0.32 & -0.5 & 2.21 & 1.52 \\
\hline ESOL Log S & -1.99 & -1.32 & -1.78 & -2.94 & -4.12 & -6.55 \\
\hline ESOL Class & Very soluble & Very soluble & $\begin{array}{l}\text { Very } \\
\text { soluble }\end{array}$ & Soluble & $\begin{array}{c}\text { Moderately } \\
\text { soluble }\end{array}$ & $\begin{array}{l}\text { Poorly } \\
\text { soluble }\end{array}$ \\
\hline $\begin{array}{l}\text { Lipinski } \\
\text { \#violations }\end{array}$ & 0 & 0 & 1 & 1 & 2 & 2 \\
\hline $\begin{array}{l}\text { Bioavailability } \\
\text { Score }\end{array}$ & 0.55 & 0.55 & 0.11 & 0.11 & 0.17 & 0.17 \\
\hline PAINS \#alerts & 0 & 0 & 0 & 0 & 0 & 0 \\
\hline Brenk \#alerts & 0 & 0 & 1 & 1 & 1 & 0 \\
\hline Fraction Csp3 & 0.44 & 0.41 & 0.41 & 0.41 & 0.48 & 0.97 \\
\hline $\begin{array}{l}\text { Synthetic } \\
\text { Accesibility }\end{array}$ & 3.63 & 2.51 & 5.04 & 5.25 & 6.33 & 8.91 \\
\hline
\end{tabular}


A.

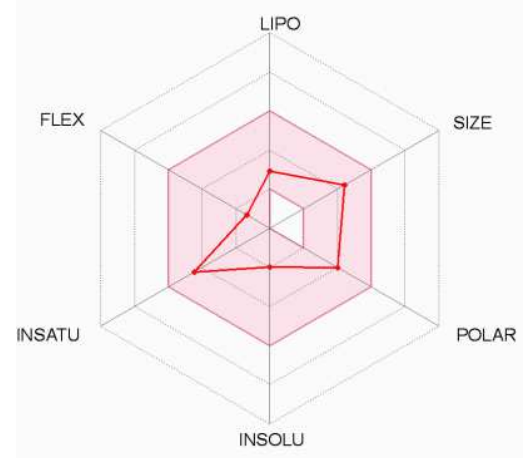

C-1 $=$ Tarivid

C

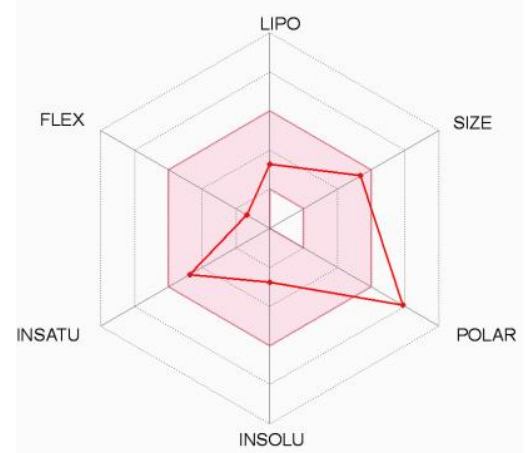

$$
\text { C-3 = Tetracycline }
$$

E

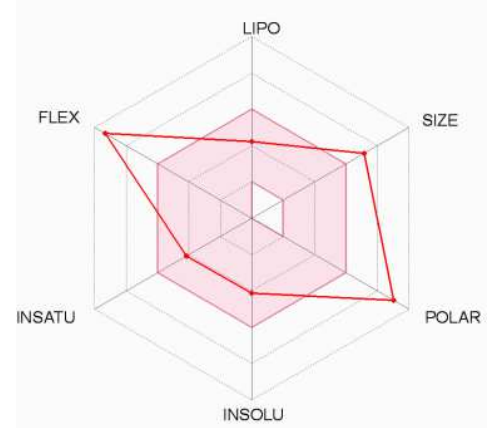

S-1 = Remdesivir

Fig. 5
B.

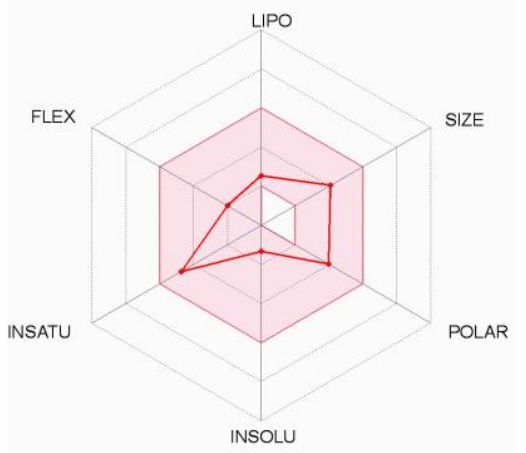

C-2 = Ciprofloxacin

$\mathrm{D}$

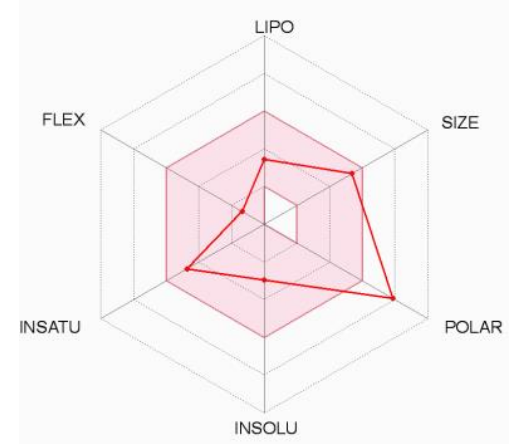

C-4 = Doxycycline

F

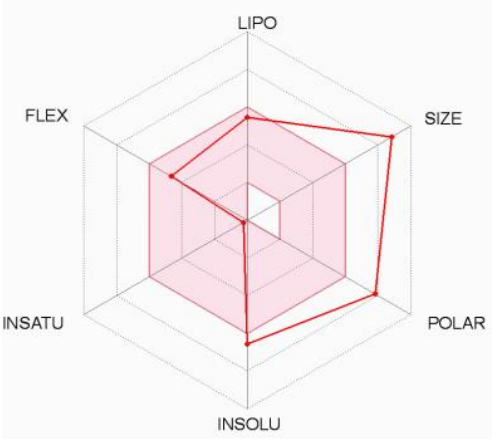

S-2 = Azithromycin

The bioavailability radar for the selected compound. 


\section{Bioactivity of the selected compounds and standards}

The bioactivity properties of the selected Antibiotics are summarized in Table 5. The relationship between the docking score and binding affinity confirmed its usage in calculating the inhibition constant $\left(\mathrm{K}_{i}\right)$ using (Equation 1). For a compound to be a Hit, its $\mathrm{K}_{i}$ value should be a micro-molar range of $0.1-1.0 \mu \mathrm{M}$ and not more than $10 \mathrm{nM}$ for a drug [34-37]. Also, the lower values of $\mathrm{Ki}$ indicate better inhibitory activity [38]. The inhibition constant values of the significantly selected antibiotics range from $(0.83-7.43 \mu \mathrm{M})$.

Table 5 Bioactivity analysis of the selected compounds and standards

\begin{tabular}{lcccccc}
\hline Bioactivity & C- 1 & C- 2 & C- 3 & C- 4 & S-1 & S-2 \\
\hline AutoDockVina docking score (kcal/mol) & -8.3 & -8.1 & -7.5 & -7.0 & -7.6 & -6.3 \\
\hline Ki $(\boldsymbol{\mu M})$ & 0.83 & 1.16 & 3.2 & 7.3 & 2.70 & 24.20 \\
\hline miLog P & -0.26 & -0.70 & -0.24 & -0.43 & 2.82 & 2.73 \\
\hline Ligand Efficiency (LE) /kcal/mol/heavy & 0.319 & 0.338 & 0.234 & 0.219 & 0.180 & 0.121 \\
atom) & & & & & & \\
\hline LE- Scale & 0.380 & 0.404 & 0.316 & 0.316 & 0.229 & 0.161 \\
\hline Fit Quality (FQ) & 0.80 & 0.80 & 0.74 & 0.692 & 0.787 & 0.752 \\
\hline Ligand-efficiency-dependent & -0.815 & -2.071 & -1.025 & -1.963 & 15.667 & 22.561 \\
lipophilicity (LELP) & & & & & & \\
\hline
\end{tabular}

$C-1=$ Tarivid, $C-2=$ Ciprofloxacin, $C 3=$ Tetracycline, $C-4=$ Doxycycline, $S-1=$ Standard 1 (Remdesivir), S-2 = Standard 2 (Azithromycin)

From Table 5, both C-1 $(0.83 \mu \mathrm{M})$ and $\mathrm{C}-2$ (1.16) are qualified as Hit while $\mathrm{C}-1$ is the most potent of all the selected compounds. For other bioactivity parameters like Ligand Efficiency (LE), Fit Quality (FQ), and Ligand-efficiency-dependent lipophilicity (LELP) (Equation 2-5), their recommended values for a hit are $\geq 0.3, \geq 0.8$ and -10 to 10 respectively [39,40]. Similarly, the (LE), (FQ) and (LELP) values observed for C-1 and C-2 are within the recommended range, although all the selected compounds obey (LELP) recommended value except S-1 and S-2 with LELP values of 15.667, and 22.5619 respectively (see Table 5).

$$
K i=e^{\left[\frac{-\Delta G}{R T}\right]}
$$


Where $R=$ Gas constant $(1.987 \times 10-3 \mathrm{kcal} / \mathrm{K}$-mol $) ; T=298.15$ (Absolute Temperature $) ; k i=$ Inhibition constant

$$
\begin{aligned}
& \text { LigandEfficiency }(L E)=-B . E \div \operatorname{Heavyatoms}(H . A) \\
& L E_{\text {scale }}=0.873 e^{-0.026 \times H . A}-0.064 \\
& F Q=L E \div L E_{\text {scale }} \\
& L E L P=\log P \div L E
\end{aligned}
$$

\section{ADMET properties of the selected compounds and standards}

The results of ADMET (absorption, distribution, metabolism, excretion, and Toxicity shown in Table 6 are computed using the ADMETSAR2 web server [25]. ADMET properties play significant roles in the early stage of drug discovery and development since high-quality drug candidates are to possess both sufficient efficacies against the therapeutic target as well as appropriate ADMET properties at a therapeutic dose [41]. Interestingly, all the selected Antibiotics and standards have an excellent probability of being absorbed in the human intestine with HIA+ values of $99.03 \%, 98.07 \%, 98.64 \%, 98.9 \%$ and $91.4 \%$ for C-1, C-2, C-3, C-4, and S1 respectively, except S-2 with HIA- (61.42\%). Also, C-1 and S-1 have an excellent probability of crossing the blood-brain barrier (BBB+ 96.8\% and 96.3\% respectively), an important pharmacokinetic property in drug discovery. Other selected drug candidates and standard show negative BBB potential; although this may not be a threat since our focus in this study is not directed towards finding potential drug candidates that target receptors in the brain, like antipsychotics, antiepileptic, and antidepressant drugs do. Furthermore, a drug molecule is expected to be in an aqueous solubility range of -1 to -5 [42] and the Log $S$ values of all the selected Antibiotics and standards fall within the range, indicating that the selected Antibioticshave good absorption and distribution potential.

Furthermore, microsomal enzymes (Cytochrome P450 inhibitors) were used to predict the metabolic activities of the selected drug candidates. All the selected drugs and standards are noninhibitors of all the cytochrome $\mathrm{P} 450$ which enhances their metabolism as potential therapeutic 
Table 6 ADMET Prediction of Selected Compounds

\begin{tabular}{|c|c|c|c|c|c|c|}
\hline \multirow[b]{2}{*}{ Parameters } & C-1 & C-2 & C-3 & C-4 & S-1 & S-2 \\
\hline & \multicolumn{6}{|c|}{ ABSORPTION/ DISTRIBUTION } \\
\hline BBB (+/-) & $\begin{array}{c}0.9680 \\
(\mathrm{BBB}+)\end{array}$ & $\begin{array}{l}0.3324 \\
\text { (BBB-) }\end{array}$ & $\begin{array}{l}0.9939 \\
(\mathrm{BBB}-)\end{array}$ & $\begin{array}{l}0.9930 \\
(\mathrm{BBB}-)\end{array}$ & $\begin{array}{c}0.9625 \\
(\mathrm{BBB}+)\end{array}$ & $\begin{array}{l}0.9930 \\
(\mathrm{BBB}-)\end{array}$ \\
\hline HIA(+/-) & $\begin{array}{c}0.9903 \\
\text { HIA+ } \\
(99.03 \%)\end{array}$ & $\begin{array}{c}0.9807 \\
\text { HIA+ } \\
(98.07 \%)\end{array}$ & $\begin{array}{c}0.9864 \\
\text { HIA+ } \\
(98.64 \%)\end{array}$ & $\begin{array}{c}0.9885 \\
\text { HIA+ } \\
(98.9 \%)\end{array}$ & $\begin{array}{c}0.9135 \\
\text { HIA+ } \\
(91.4 \%)\end{array}$ & $\begin{array}{c}0.6142 \\
\text { HIA- } \\
(61.42 \%)\end{array}$ \\
\hline $\begin{array}{l}\text { Aqueous } \\
\text { Solubility(LogS) }\end{array}$ & -3.511 & -3.464 & -3.071 & -3.057 & -3.474 & -2.06 \\
\hline
\end{tabular}

\begin{tabular}{|c|c|c|c|c|c|c|}
\hline $\begin{array}{l}\text { CYP450 2C19 } \\
\text { Inhibitor }\end{array}$ & $\begin{array}{c}0.9026 \\
\text { Non- } \\
\text { Inhibitor }\end{array}$ & $\begin{array}{c}0.9025 \\
\text { Non- } \\
\text { Inhibitor }\end{array}$ & $\begin{array}{c}0.9099 \\
\text { Non- } \\
\text { Inhibitor }\end{array}$ & $\begin{array}{c}0.9089 \\
\text { Non- } \\
\text { Inhibitor }\end{array}$ & $\begin{array}{c}0.7362 \\
\text { Non- } \\
\text { Inhibitor }\end{array}$ & $\begin{array}{c}0.9023 \\
\text { Non- } \\
\text { Inhibitor }\end{array}$ \\
\hline $\begin{array}{l}\text { CYP450 1A2 } \\
\text { Inhibitor }\end{array}$ & $\begin{array}{c}0.9045 \\
\text { Non- } \\
\text { Inhibitor }\end{array}$ & $\begin{array}{c}0.7735 \\
\text { Non- } \\
\text { Inhibitor }\end{array}$ & $\begin{array}{c}0.9045 \\
\text { Non- } \\
\text { Inhibitor }\end{array}$ & $\begin{array}{c}0.9046 \\
\text { Non- } \\
\text { Inhibitor }\end{array}$ & $\begin{array}{c}0.7447 \\
\text { Non- } \\
\text { Inhibitor }\end{array}$ & $\begin{array}{c}0.9295 \\
\text { Non- } \\
\text { Inhibitor }\end{array}$ \\
\hline $\begin{array}{l}\text { CYP450 3A4 } \\
\text { Inhibitor }\end{array}$ & $\begin{array}{c}0.8309 \\
\text { Non- } \\
\text { Inhibitor }\end{array}$ & $\begin{array}{c}0.8309 \\
\text { Non- } \\
\text { Inhibitor }\end{array}$ & $\begin{array}{c}0.8567 \\
\text { Non- } \\
\text { Inhibitor }\end{array}$ & $\begin{array}{c}0.8686 \\
\text { Non- } \\
\text { Inhibitor }\end{array}$ & $\begin{array}{c}0.7224 \\
\text { Non- } \\
\text { Inhibitor }\end{array}$ & $\begin{array}{c}0.9533 \\
\text { Non- } \\
\text { Inhibitor }\end{array}$ \\
\hline $\begin{array}{l}\text { CYP450 2C9 } \\
\text { Inhibitor }\end{array}$ & $\begin{array}{c}0.9070 \\
\text { Non- } \\
\text { Inhibitor }\end{array}$ & $\begin{array}{c}0.9070 \\
\text { Non- } \\
\text { Inhibitor }\end{array}$ & $\begin{array}{c}0.9144 \\
\text { Non- } \\
\text { Inhibitor }\end{array}$ & $\begin{array}{c}0.9071 \\
\text { Non- } \\
\text { Inhibitor }\end{array}$ & $\begin{array}{c}0.7246 \\
\text { Non- } \\
\text { Inhibitor }\end{array}$ & $\begin{array}{c}0.9021 \\
\text { Non- } \\
\text { Inhibitor }\end{array}$ \\
\hline $\begin{array}{l}\text { CYP450 2D6 } \\
\text { Inhibitor }\end{array}$ & $\begin{array}{c}0.9268 \\
\text { Non- } \\
\text { Inhibitor }\end{array}$ & $\begin{array}{c}0.9231 \\
\text { Non- } \\
\text { Inhibitor }\end{array}$ & $\begin{array}{c}0.9293 \\
\text { Non- } \\
\text { Inhibitor }\end{array}$ & $\begin{array}{c}0.9231 \\
\text { Non- } \\
\text { Inhibitor }\end{array}$ & $\begin{array}{c}0.8503 \\
\text { Non- } \\
\text { Inhibitor }\end{array}$ & $\begin{array}{c}0.8904 \\
\text { Non- } \\
\text { Inhibitor }\end{array}$ \\
\hline \multicolumn{7}{|c|}{ EXCRETION } \\
\hline *Biodegradation & $\begin{array}{l}0.9500 \\
\mathrm{NB}\end{array}$ & $\begin{array}{c}0.8500 \\
\mathrm{NB}\end{array}$ & $\begin{array}{c}0.9750 \\
\mathrm{NB}\end{array}$ & $\begin{array}{c}0.9750 \\
\mathrm{NB}\end{array}$ & $\begin{array}{c}0.7750 \\
\mathrm{NB}\end{array}$ & $\begin{array}{c}0.8250 \\
\mathrm{NB}\end{array}$ \\
\hline
\end{tabular}

\section{TOXICITY}

\begin{tabular}{lcccccc}
\hline AMES Toxicity & $\begin{array}{c}0.7300 \\
\text { Non-Ames } \\
\text { Toxic }\end{array}$ & $\begin{array}{c}0.8900 \\
\text { Ames Toxic }\end{array}$ & $\begin{array}{c}0.6300 \\
\text { Non-Ames } \\
\text { Toxic }\end{array}$ & $\begin{array}{c}0.7200 \\
\text { Non-Ames } \\
\text { Toxic }\end{array}$ & $\begin{array}{c}0.7400 \\
\text { Non-Ames } \\
\text { Toxic }\end{array}$ & $\begin{array}{c}0.8300 \\
\text { Non-Ames } \\
\text { Toxic }\end{array}$ \\
\hline $\begin{array}{l}\text { Acute Oral } \\
\text { Toxicity }\end{array}$ & $\begin{array}{c}0.7916 \\
\text { III }\end{array}$ & $\begin{array}{c}0.7731 \\
\text { III }\end{array}$ & $\begin{array}{c}0.7981 \\
\text { III }\end{array}$ & $\begin{array}{c}0.7834 \\
\text { III }\end{array}$ & $\begin{array}{c}0.5357 \\
\text { III }\end{array}$ & $\begin{array}{c}0.7761 \\
\text { III }\end{array}$ \\
$\begin{array}{l}\text { Eye Irritation } \\
\text { (YES/NO) }\end{array}$ & NO & NO & NO & NO & NO & NO \\
\hline $\begin{array}{l}\text { Eye Corrosion } \\
\text { (YES/NO) }\end{array}$ & NO & NO & NO & NO & NO & NO \\
\hline hERG Inhibition & $\begin{array}{c}0.8179 \\
\text { NO }\end{array}$ & $\begin{array}{c}0.8225 \\
\text { NO }\end{array}$ & $\begin{array}{c}0.3636 \\
\text { NO }\end{array}$ & $\begin{array}{c}0.3965 \\
\text { NO }\end{array}$ & $\begin{array}{c}0.5000 \\
\text { NO }\end{array}$ & $\begin{array}{c}0.6048 \\
\text { NO }\end{array}$ \\
\hline Carcinogenicity & $\begin{array}{c}0.7286 \\
\text { Non- }\end{array}$ & $\begin{array}{c}0.8043 \\
\text { Non- } \\
\text { Carcinogenic }\end{array}$ & $\begin{array}{c}0.8539 \\
\text { Carcinogenic }\end{array}$ & $\begin{array}{c}0.9429 \\
\text { Carcinogenic } \\
\text { Non- }\end{array}$ & $\begin{array}{c}0.9714 \\
\text { Carcinogenic } \\
\text { Carcinogenic }\end{array}$ & $\begin{array}{c}0.9857 \\
\text { Non- } \\
\text { Carcinogenic }\end{array}$
\end{tabular}

*NB: Not biodegradable

$C-1=$ Tarivid, $C-2=$ Ciprofloxacin, $C-3=$ Tetracycline, $C-4=$ Doxycycline, $S-1=$ Standard 1 (Remdesivir), $S-2=$ Standard 2 (Azithromycin) 
drugs. Although all the selected Antibiotics and standards are predicted to be non-biodegradable nevertheless, they are non-carcinogenic. Considering the AMES toxicity of the selected Antibiotics and standards i.e. their mutagenic abilities, all except compound C-2 are non-AMEStoxic. Also, all the selected compounds and standards possess type III oral acute toxicity indicating that they are slightly toxic although they show no eye irritation and corrosion. However, type III toxicity can easily be upgraded to type IV and become (non-toxic) during the lead optimization stage of drug discovery [43]. The ability of a drug molecule to inhibit human ether a-go-go (hERG) is very dangerous, as it can lead to blockage of the potassium ion channel of the myocardium which disrupts the electrical activity of the heart and may result to untimely death [44]. Interestingly, all the selected Antibiotics and standards are non-inhibitor of hERG with compound $\mathrm{C}-1$ and $\mathrm{C}-2$ having the better potential of being non-inhibitor of hERG. Summarily, all the selected compounds are safer and excellent drug candidates against the target receptor.

\section{Binding modes and Molecular interactions}

The binding mode and molecular interactions give more information on the interacting mode of the selected Antibiotics with a bond to the main protease $\left(\mathrm{M}^{\text {pro }}\right)$. Since compound $\mathrm{C}-1$ and $\mathrm{C}-2$ give better inhibitory potential and promising physicochemical and bioactivity properties among the four selected compounds, only their binding mode and molecular interactions are discussed. As shown in Fig. 6 and 7, the binding modes of the two selected hit compounds ( $\mathrm{C}-1$ and $\mathrm{C}-2)$ and fully embedded in the binding pocket located at the cleft between domains I and II which is the active site of the target protease $\left(\mathrm{M}^{\mathrm{pro}}\right)$ (see Table 1). The nonbonded molecular interactions of C-1(Fig. 8) as seen in AutoDock Vina docking results include: Conventional Hydrogen Bond with Glu166, Carbon-Hydrogen Bond with Phe140, Asn142 and Arg188, Pi-Pi T-Shaped with His41 and Alkyl and Pi-Alkyl interactions with Met49 and Met165. Similarly, C-2(Fig. 7) form Conventional Hydrogen Bond with Gln189, Glu166 and Phe140, Carbon-Hydrogen Bond with Leu141, and Asn142, Pi-Pi T-Shaped interaction with His41 and Alkyl and Pi-Alkyl interactions with Cys145, Met49 and Met145. However, the presence of His41, Met49, Phe140, Asn142, Met165, and Glu166 amino acid residues in both 
compounds (C-1 and C-2) established that the two compounds have a similar binding pocket and confirmed the similarity in their mode of interactions. Various interactions exhibit by other selected compounds (C-3 and C-4) are shown in (Fig. 8). Finally, a close examination of the amino acid residues obtained in the interactions of C-1, C-2, C-3 and C-4 (Fig. 8), and the amino acids in the active site (Table 2) affirmed that all the selected antibiotics share the same binding pocket with N3 native ligand, although C-1 (Tarivid) and C-2 (Ciprofloxacin) are more potent and interact better with target receptor $\left(\mathrm{M}^{\mathrm{pro}}\right)$.

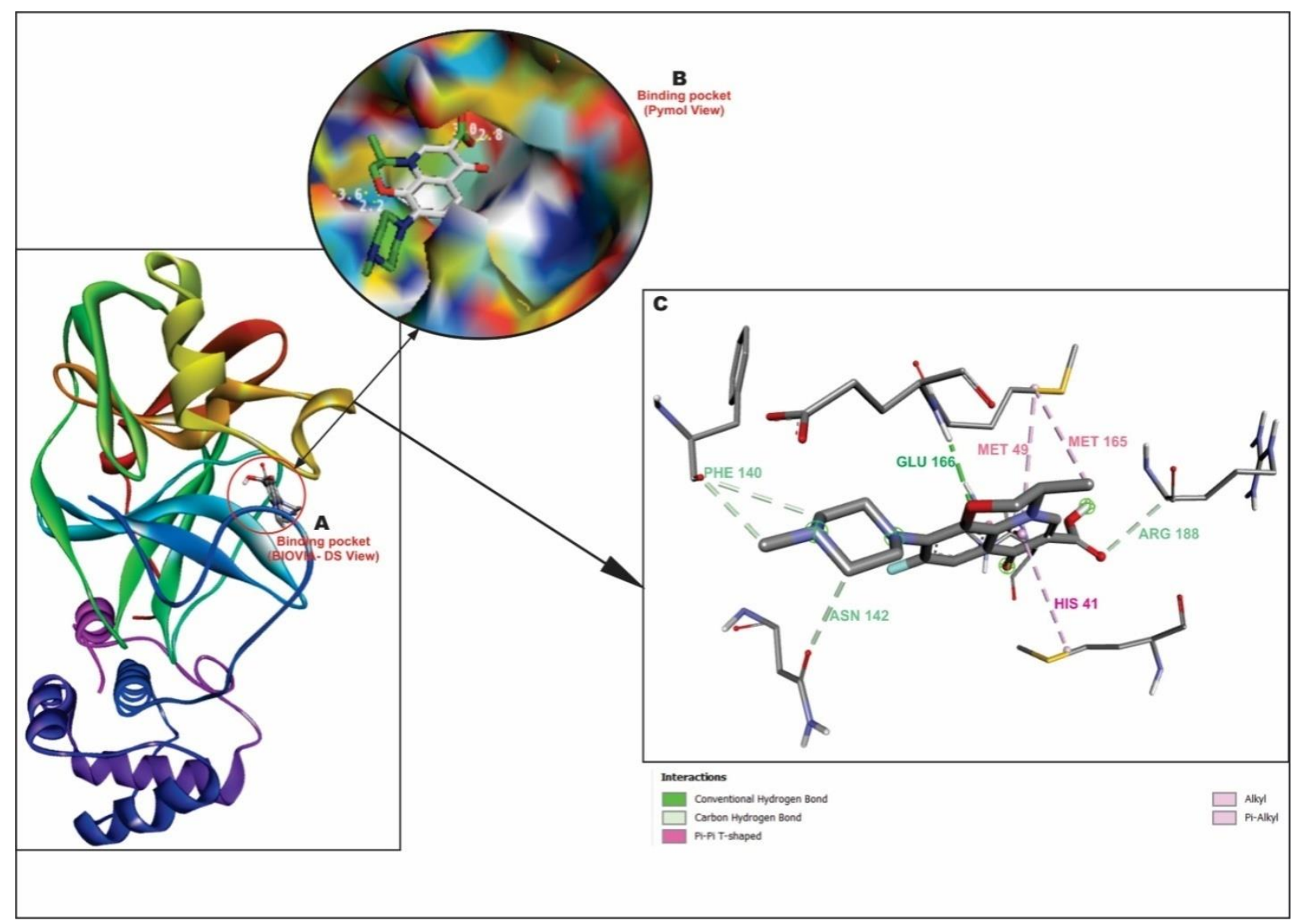

Fig. 6 The binding pockets (A \& B) and binding mode (C) of C-1 (Tarivid) with amino acids in SARS-CoV-2M $\mathrm{M}^{\text {pro }}(6 \mathrm{LU} 7)$ 


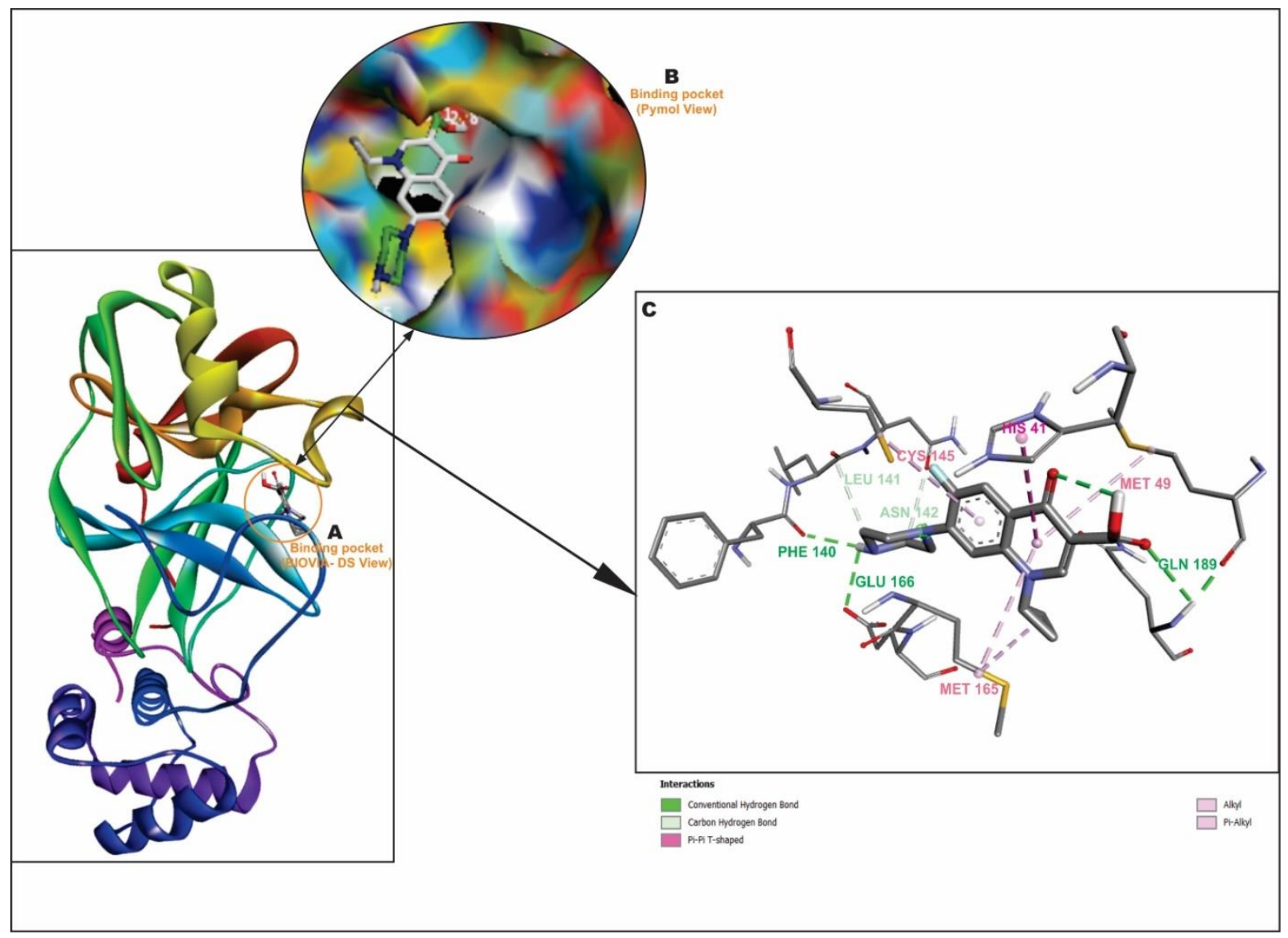

Fig. 7 The binding pockets (A \& B) and binding mode (C) of C-2 (Ciprofloxacin) with amino acids in SARS-CoV-2 $\mathrm{M}^{\text {pro }}(6 \mathrm{LU} 7)$ 


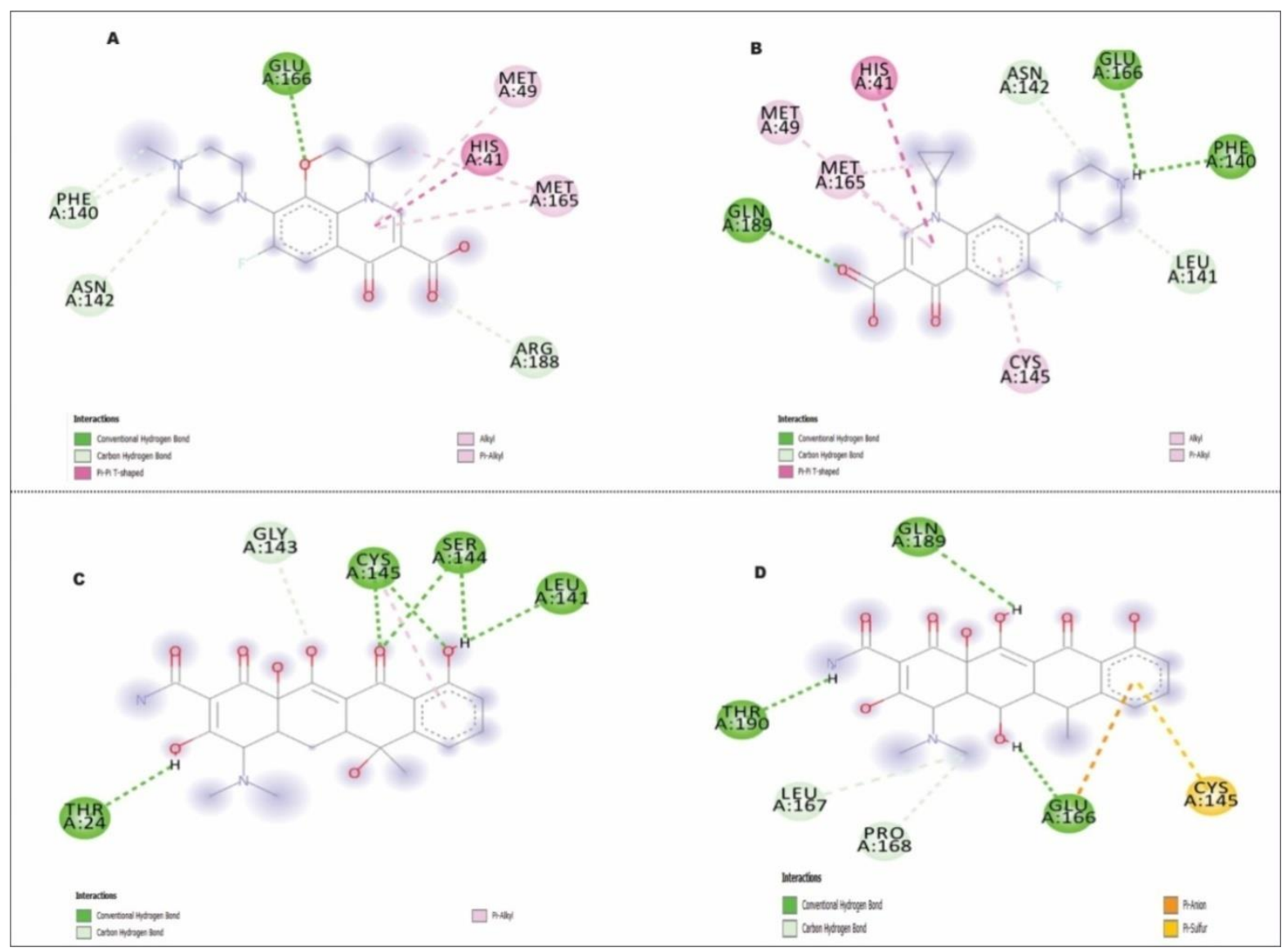

Fig. 8 The molecular interactions of C-1 (Tarivid), C-2 (Ciprofloxacin), C-3 (Tetracycline) and C-4 (Doxycycline) with amino acids in SARS-CoV-2M $\mathrm{M}^{\text {pro }}$ (6LU7)

\section{Conclusions}

As the world enters the second wave of the global pandemic (COVID-19) with no officially approved drug to apprehend the disease, the need for improving on intensive research through screening of phytochemicals, laboratory synthesis of novel drug candidates and repurposing odd drugs among other means becomes a necessity. Computer-Aided Drug Design $(\mathrm{CADD})$ is an indispensable tool to accelerate the discovery and development of a new therapeutic agent to cure this lingering disease that has claimed lives in millions. Some drugs have been proved and approved to be effective for curing more than one disease. Therefore, the current research used CADD approach via molecular docking coupled with other relevant analyses to screen some commercial antibiotics against SARS-CoV-2 main protease (M ${ }^{\text {pro }}$ ) (6LU7) and identified two antibiotics (Tarivid and Ciprofloxacin) as probable inhibitors of the target receptor responsible for replication and transcription of the virus. As reported by 
Burlingham and Widlanski, 2003, compound with lower inhibition constant value has higher inhibitory efficiency, thus, the binding affinities $(\mathrm{kcal} / \mathrm{mol})$ and inhibition constant $(\mu \mathrm{M})$ of both compounds (Tarivid, $-8.3 \mathrm{kcal} / \mathrm{mol}, 0.83 \mu \mathrm{M}$ ) and (Ciprofloxacin, $-8.1 \mathrm{kcal} / \mathrm{mol}, 1.16 \mu \mathrm{M}$ ) obtained from their interaction with the active site of the target receptor qualified them as hits. The two hit compounds interacted and shared the same pocket with the active site of the receptor located at the cleft between domains I and II. Both compounds obeyed the drug-likeness rule (RO5 rule of Lipinski) and show outstanding bioactivity and oral-bioavailability properties as compared to the two standards (Remdesivir and Azithromycin) whose randomized clinical trials have been completed [45]. Also, ADMET profiling of the two hits revealed their ability to be absorbed easily in human intestine. Both are non-inhibitors of cytochrome P450, non-carcinogenic and non-hERG inhibitors, although, their potency, efficacy, pharmacokinetics and reduced toxicity can be improved during the Hit-Lead optimization stage of drug discovery. The importance of in vivo and in vitro experiments to further establish the potency of the two hits compounds are dully acknowledged, but lack of financial aid limited our scope. We thereby recommend these two hit compounds for further experimental studies and clinical trials in the quest of finding a lasting solution to the ravaging pandemic (COVID-19).

Authors' contributions Misbaudeen Abdul-Hammed and Ibrahim Olaide Adedotun: Conceptualization, Methodology, Validation, Supervision, Writing-Review \& Editing, Visualization, Data curation, Resources.

Victoria Adeola Falade and Modinat Wuraola Akinboade: Writing - Original Draft, Writing-Review \& Editing, Methodology, Investigation, Data curation, Visualization.

Adewusi John Adepoju and Sabitu Babatunde Olasupo: Conceptualization, Methodology, Data curation, Investigation, Visualization, Supervision.

Funding No funding was received for conducting this study

Data availability All data generated or analyzed during this study are included in this article. 
Acknowledgment The authors wish to acknowledge members of the Computational and Biophysical Chemistry group in the Department of Pure and Applied Chemistry, Ladoke Akintola University of Technology, LAUTECH, Ogbomoso, Nigeria.

\section{Compliance with ethical standards}

Conflict of interest The authors have no conflicts of interest to declare that are relevant to the content of this article.

Ethics approval NA

Consent to participate NA

Consent for Publication NA

Code availability NA 


\section{References}

[1] Chan JF, Yuan S, Kok KH et al (2020) A familial cluster of pneumonia associated with the 2019 novel coronavirus indicating person-to-person transmission: A study of a family cluster. Lancet 395:514-523. https://doi.org/10.1016/S0140-6736(20)30154-9

[2] Chang L, Yan Y, Wang L (2020) Coronavirus Disease 2019: Coronaviruses and Blood Safety. Transfus Med Rev 34:75-80. https://doi.org/10.1016/j.tmrv.2020.02.003.

[3] Chen N, Zhou M, Dong X et al ( 2020) Epidemiological and clinical characteristics of 99 cases of 2019 novel coronavirus pneumonia in Wuhan, China: A descriptive study. Lancet 395:507-513. https://doi.org/10.1016/S0140-6736(20)30211-7

[4] Carlet J, Collignon P, Goldmann D et al (2011) Society's failure to protect a precious resource: Antibiotics. Lancet 378:369-371. https://doi.org/10.1016/S0140-6736(11)604017

[5] Adedeji WA (2016) The treasure called antibiotics. Ann Ibadan Postgrad Med 14:56-57.

[6] Tanday S (2016) Resisting the use of antibiotics for viral infections. Lancet Respir Med 4:179. https:/doi.org/10.1016/S2213-2600(16)00060-6

[7] Cals JWL, Boumans D, Lardinois RJM, Gonzales R, Hopstaken RM, Butler CC, Dinant GJ (2007) Public beliefs on antibiotics and respiratory tract infections: an internet-based $\begin{array}{llllll}\text { questionnaire } & \text { study. } & \mathrm{Br} & \mathrm{J} & \mathrm{Gen} & \text { Pract }\end{array}$ https://doi.org/10.3399/096016407782605027

[8] Karst SM (2016) The influence of commensal bacteria on infection with enteric viruses. Nat Rev Microbiol 14:197-205. https://doi.org/10.1038/nrmicro.2015.25

[9] Gopinath S, Kim MV, Rakib T, Wong PW, van Zandt M, Barry NA, Kaisho T, Goodman AL, Iwasaki A (2018) Topical application of aminoglycoside antibiotics enhances host 
resistance to viral infections in a microbiota-independent manner. Nat Microbiol 3:611621. https://doi.org/10.1038/s41564-018-0138-2

[10] Gopinath S, Lu P, Iwasaki A, Alerts E (2020) Cutting Edge: The Use of Topical Aminoglycosides as an Effective Pull-in 'Prime and Pull' Vaccine Strategy. J Immunol 204:1703-1707. https://doi.org/10.4049/jimmunol.1900462

[11] Miller A, Reandelar MJ, Fasciglione K, Roumenova V, Li Y, Otazu GH (2020) Correlation between universal BCG vaccination policy on reduced morbidity and mortality for covid-19: an epidemiology study. MedRxi. https://doi.org/10.1101/2020.03.24.20042937

[12] Retallack H, Di E, Arias C et al (2016) Zika virus cell tropism in the developing human brain and inhibition by azithromycin. Proc Natl Acad Sci 113:14408-14413. https://doi.org/10.1073/pnas.1618029113

[13] Tran DH, Sugamata R, Hirose T et al (2019) Azithromycin, a 15-membered macrolide antibiotic, inhibits influenza A (H1N1) pdm09 virus infection by interfering with virus internalization process. J Antibiot 72:759-768. https://doi.org/10.1038/s41429-019-0204-X

[14] Colson P, Rolain J, Raoult D (2020) Chloroquine for the 2019 novel coronavirus SARS$\begin{array}{lllll}\text { CoV-2. Int } & \mathrm{J} & \text { Antimicrob } & \text { Agents }\end{array}$ https://doi.org/10.1016/j.ijantimicag.2020.105923

[15] Gautret P, Lagier J, Parola P et al (2020) Hydroxychloroquine and azithromycin as a treatment of COVID-19: results of an open-label non-randomized clinical trial. Int J Antimicrob Agents 56:10549. https://doi.org/10.1016/j.ijantimicag.2020.105949

[16] Cortegiani A, Ingoglia G, Ippolito M, Giarratano A, Einav S (2020) A systematic review on the efficacy and safety of chloroquine for the treatment of COVID-19. J Crit Care 
57:279-283. https://doi.org/10.1016/j.jcrc.2020.03.005

[17] Wang JM, Cao R, Zhang L, Yang X, Liu J, Xu M, Shi Z, Hu Z, Zhong W, Xiao G (2020) Remdesivir, and chloroquine effectively inhibit the recently emerged novel coronavirus (2019-nCoV) in vitro. Cell Res 30:269-271. https://doi.org/10.1038/s41422-020-0282-0

[18] Caly L, Druce JD, Catton MG, Jans DA, Wagsta, KM (2020) The FDA-approved drug Ivermectin inhibits the replication of SARS-CoV-2 in vitro. Antiviral Res 178:104787. https://doi.org/10.1016/j.antiviral.2020.104787

[19] Lythgoe MP, Middleton P (2020) Ongoing Clinical Trials for the Management of the COVID-19 Pandemic. Trends Pharmacol Sci 41:363-382. https://doi.org/10.1016/j.tips.2020.03.006

[20] Li Y, Zhang J, Wang N, Li H, Shi Y, Guo G, Liu K, Zeng H, Zou Q (2020) Therapeutic Drugs Targeting 2019-nCoV Main Protease by High-Throughput Screening. BioRxiv https://doi.org/10.1101/2020.01.28.922922

[21] Biovia DS (2015) DiscoveryStudioModelingEnvironment.

[22] Tian W, Chen C, Lei X, Zhao J, Liang J (2018) CASTp 3.0: computed atlas of surface topography of proteins. Nucleic Acids Res 46:W363-W367. https://doi.org/ 10.1093/nar/gky473

[23] Liu x, Zhang B, Jin Z, Yang H, Rao Z (2020) Structure of M ${ }^{\text {pro }}$ from COVID-19 virus and discovery of its inhibitors. Nature. 582:289-293. https://doi.org/10.1038/s41586-0202223-y

[24] Trott O, Olson AJ (2010) Software News and Update AutoDock Vina: Improving the Speed and Accuracy of Docking with a New Scoring Function, Efficient Optimization, and Multithreading. J Comput Chem 31:455-461. https://doi.org/10.1002/jcc.21334 
[25] Cheng F, Li W, Zhou Y, Shen J, Wu Z, Liu G, Lee PW, Tang Y (2012) admetSAR: A Comprehensive Source and Free Tool for Assessment of Chemical ADMET Properties. 52:3099-3105. https://doi.org/10.1021/ci300367a

[26] Ferreira LG, Santos RN, Oliva G, Andricopulo AD (2015) Molecular Docking and Structure-Based Drug Design $\quad$ Strategies.Molecules. $\quad$ 20:13384-13421. https://doi.org/10.3390/molecules200713384

[27] López-vallejo F, Caulfield T, Martínez-Mayorga K, Giulianotti MA, Nefzi A, Houghten RA, Medina-Franco JL (2011) Integrating Virtual Screening and Combinatorial Chemistry for Accelerated Drug Discovery. Comb Chem High Throughput Screen 14:475-487. https://doi.org/10.2174/138620711795767866

[28] Huang S, Zou X (2010) Advances and Challenges in Protein-Ligand Docking. Int J Mol Sci 11:3016-3034. https://doi.org/10.3390/ijms11083016

[29] Sodhi M, Etminan M (2020) Therapeutic Potential for Tetracyclines in the Treatment of Covid-19. Pharmacother 40:1-2. https://doi.org/10.1002/phar.2395

[30] Hara Y, Hanjo Y (2019) Ofloxacin and Levofloxacin (Tarivi/Cravit). In: Nagaoka S (ed) Drug Discovery in Japan. Springer, Singapore, pp 85-110

[31] Khan AF, Basir R (1989) Sequential Intravenous-Oral Administration of Ciprofloxacin vs Ceftazidime in Serious Bacterial Respiratory Tract Infections. Chest 96:528-537. https://doi.org/10.1378/chest.96.3.528

[32] Lipinski CA (2004) Lead, and drug-like compounds : the rule-of-five revolution. Drug Discov Today 1:337-341. https://doi.org/10.1016/j.ddtec.2004.11.007 
[33] Daina A, Zoete V (2016) A boiled-egg to predict gastrointestinal absorption and brain penetration of small molecules. ChemMed-Chem. 11:1117-1121. https://doi.org/10.1002/cmdc.201600182

[34] Bohacek RS, Mcmartin C, Guida WC (1996) The Art and Practice of Structure-Based Drug Design: A Molecular Modeling Perspective. Med Res Rev 16:3-50. https://doi.org/10.1002/(SICI)1098-1128(199601)16:1<3::AID-MED1>3.0.CO;2-6

[35] Hughes JP, Rees S, Kalindjian SB, Philpott KL (2011) Principles of early drugdiscovery. Br J Pharmacol 162:1239-1249. https://doi.org/10.1111/j.1476-5381.2010.01127.x

[36] Stevens E (2014) Lead Discovery. In: Jaworski A (ed) Medicinal Chemistry: Modern Drug Discovery Process. Pearson, pp 247-272

[37] Schultes S, Kooistra A, Vischer HF , Nijmeijer S, Haaksma EE, Leurs Rob, De Esch IJP, de Graaf C (2015) Combinatorial Consensus Scoring for Ligand-Based Virtual Fragment Screening:A Comparative Case Study for Serotonin 5-HT 3 A, Histamine H 1 and Histamine H 4 Receptors. J Chem Inf Model 55:1030-1044. https://doi.org/10.1021/ci500694c

[38] Burlingham BT, Widlanski TS (2003) An Intuitive Look at the Relationship of $\mathrm{K}_{\mathrm{i}}$ and IC50: A More General Use for the Dixon Plot. J Chem Educ 80:214-218. https://doi.org/10.1021/ed080p214

[39] Schultes S, De Graaf C, Haaksma EEJ, De Esch IJP, Leurs R, Kramer O (2010) Ligand efficiency as a guide in fragment hit selection and optimization. Drug Discov Today Technol 7:e157-e162. https://doi.org/10.1016/j.ddtec.2010.11.003

[40] Hopkins AL, Keserü GM, Leeson PD, Rees DC, Reynolds CH (2014) The role of ligand efficiency metrics in drug discovery. Nat Rev Drug Discov 13:105-121. 
https://doi.org/10.1038/nrd4163

[41] Guan L, Yang H, Cai Y, Sun L, Di P, Li W, Liu G, Tang Y (2018) ADMET-score-a comprehensive scoring function for evaluation of chemical drug-likeness. Med Chem Commun 10:148-157. https.//doi.org/10.1039/c8md00472b

[42] Bergenhem N (2011) Preclinical candidate nomination and development, In: Tsaioun K Kate SA (eds) Admet For Medicinal Chemists. John Wiley and Sons, Singapore, pp 399415.

[43] Onawole AT, Sulaiman KO, Adegoke RO, Kolapo TU (2017) Identification of potential inhibitors against the Zika virus using consensus scoring. J Mol Graph Mod 73:54-61. https://doi.org/10.1016/j.jmgm.2017.01.018

[44] Sanguinetti MC, Tristani-firouzi M (2006) hERG potassium channels and cardiac arrhythmia. Nature. 440:463-469. https://doi.org/10.1038/nature04710

[45] Kaddoura M, AlIbrahim M, Hijazi G, Soudani N, Audi A, Alkalamouni H, Haddad S, Eid A, Zaraket H (2020) COVID-19 Therapeutic Options Under Investigation. Front Phatmacol 11:1196 
Figures

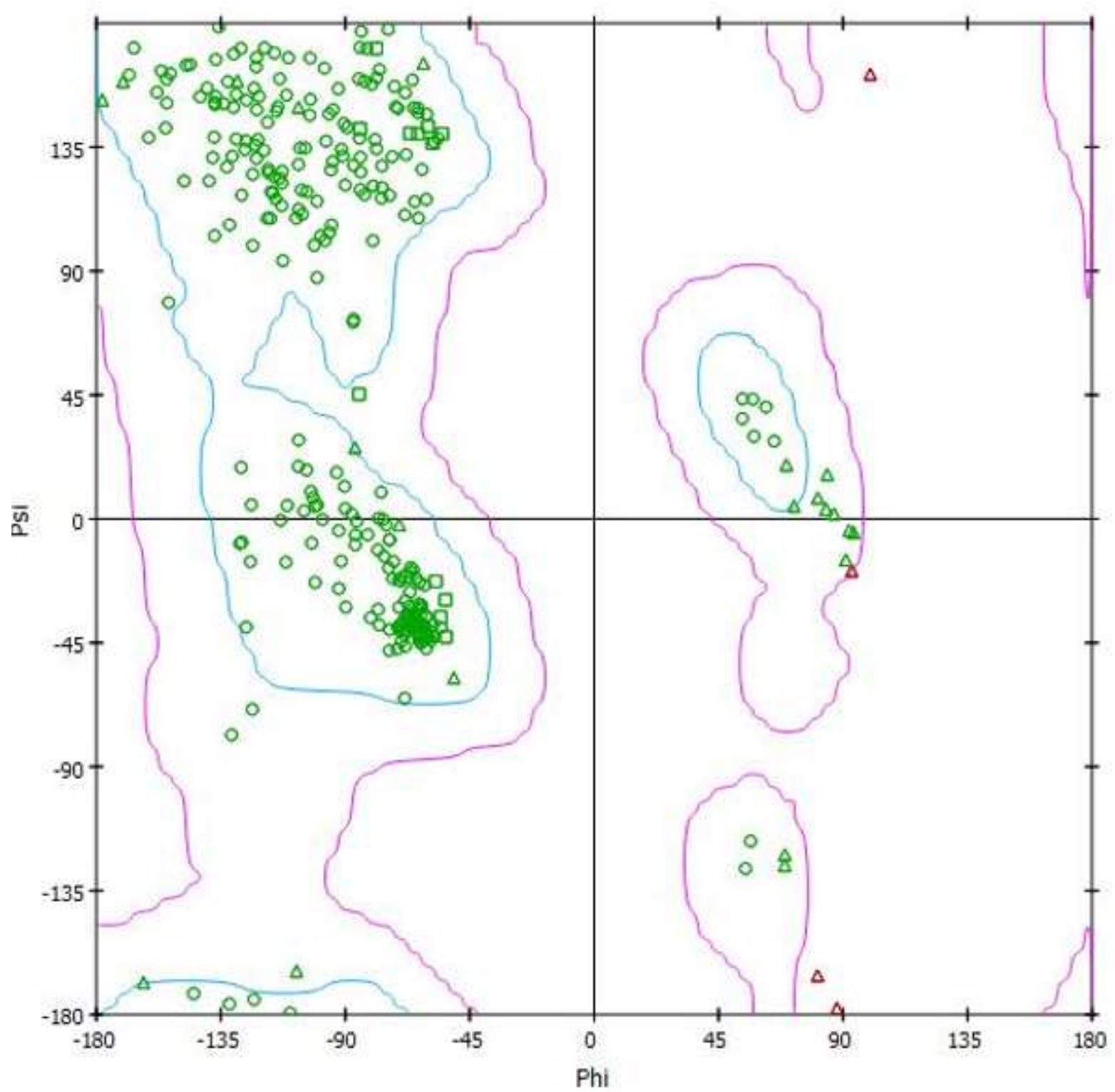

Figure 1

The Ramachandran plot of SARS-CoV-2 Mpro (6LU7) 


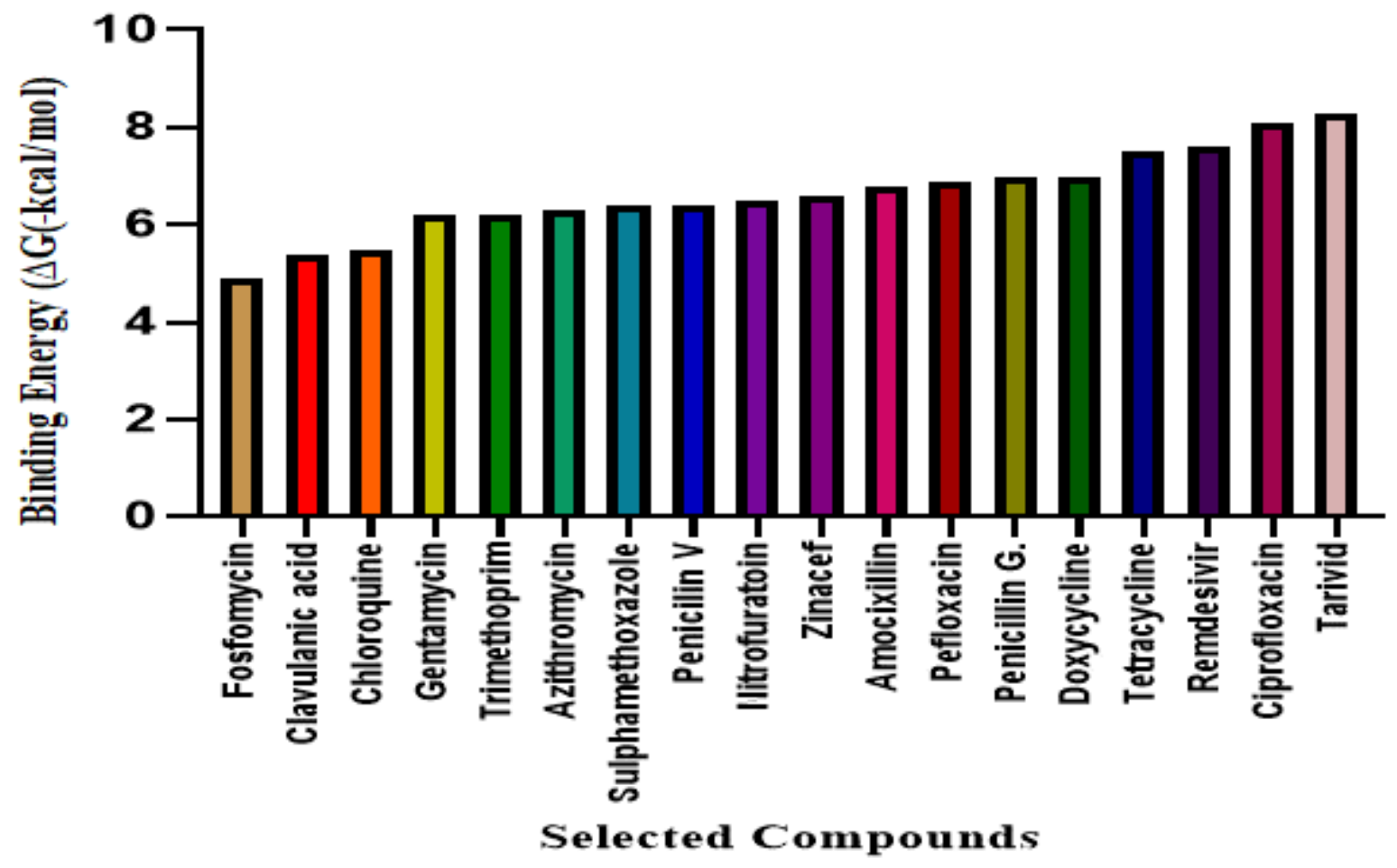

Figure 2

The bar chart showing the molecular docking scores between Mpro (6LU7) and selected drug candidate compounds. (The value for binding energy $(\Delta \mathrm{G})$ is indicated in minus $\mathrm{kcal} / \mathrm{mol}$ )
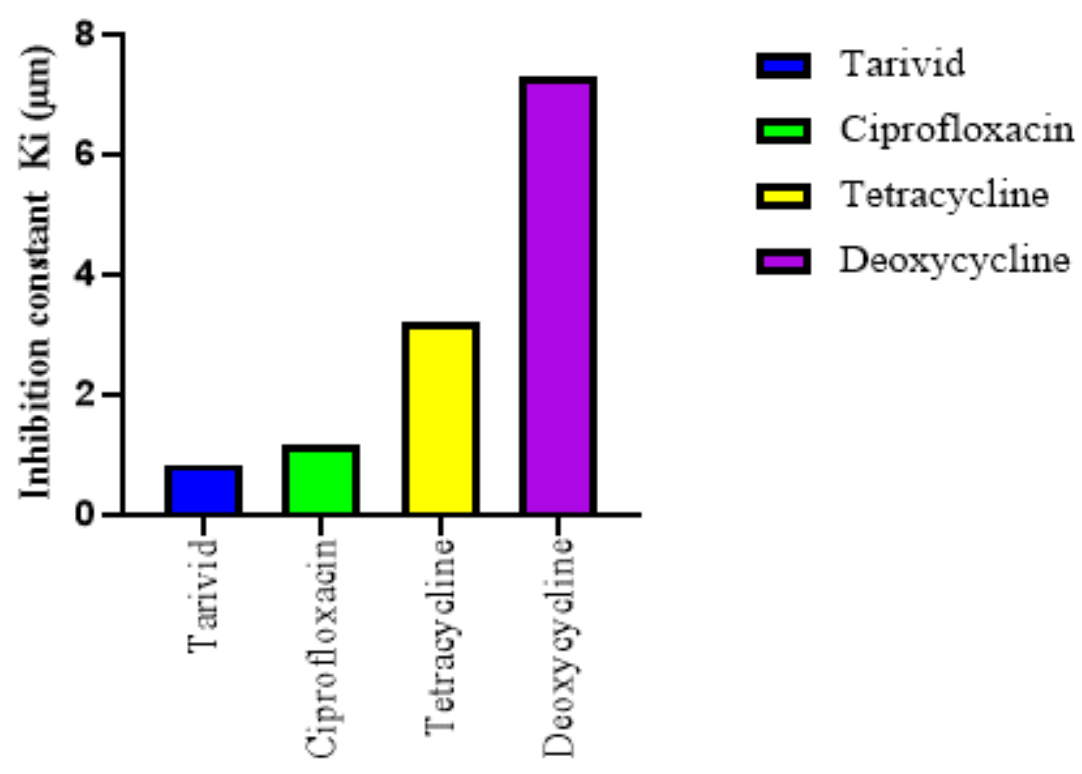

Selected Compounds

Figure 3 
The bar chart showing the selected Antibiotics as significant potential inhibitor of SARS-CoV-2MPro<smiles>CC1COc2c(N3CCN(C)CC3)c(F)cc3c(=O)c(C(=O)O)cn1c23</smiles>

$\mathbf{A}$<smiles>O=C(O)c1cn(C2CC2)c2cc(N3CCNCC3)c(F)cc2c1=O</smiles><smiles>CN(C)C1C(=O)C(C(N)=O)=C(O)C2(O)C(=O)C3=C(O)c4c(O)cccc4C(C)(O)C3CC12</smiles><smiles>CC1c2cccc(O)c2C(O)=C2C(=O)C3(O)C(O)=C(C(N)=O)C(=O)C(N(C)C)C3C(O)C21</smiles>

Figure 4

The Structures of Selected Compounds (a) Tarivid (b) Ciprofloxacin (c) Tetracycline (d) Doxycycline 
A.

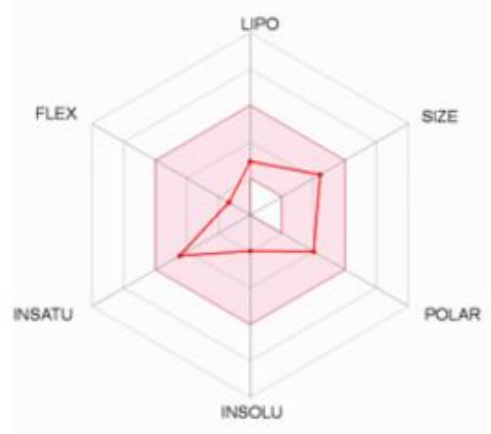

$\mathrm{C}-1=$ Tarivid

C

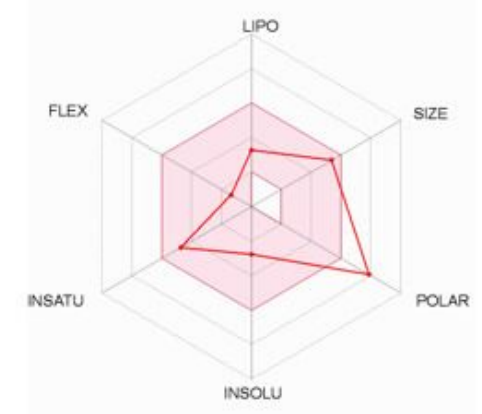

C-3 = Tetracycline

E

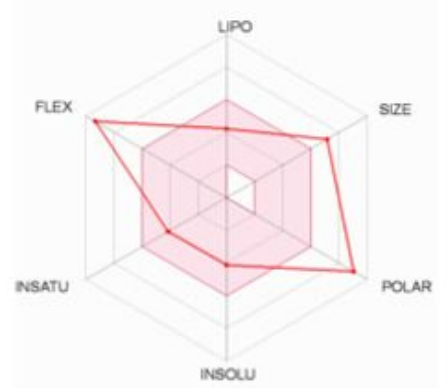

S-1 = Remdesivir
B.

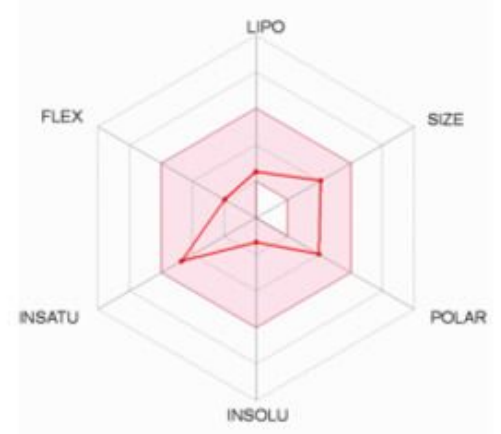

$$
\text { C-2 = Ciprofloxacin }
$$

D

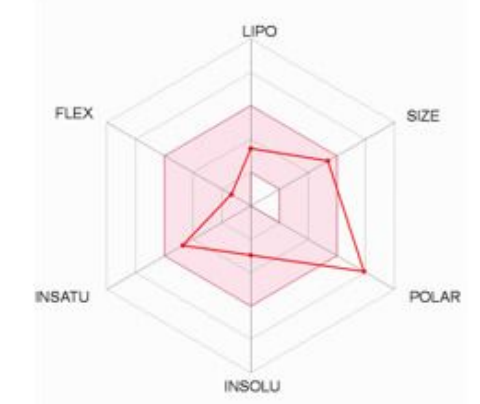

C-4 = Doxycycline

F

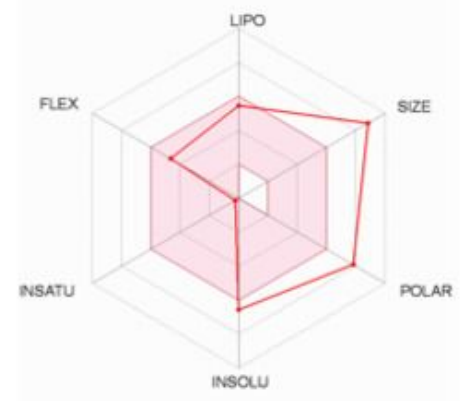

S-2 = Azithromycin

\section{Figure 5}

The bioavailability radar for the selected compound. 


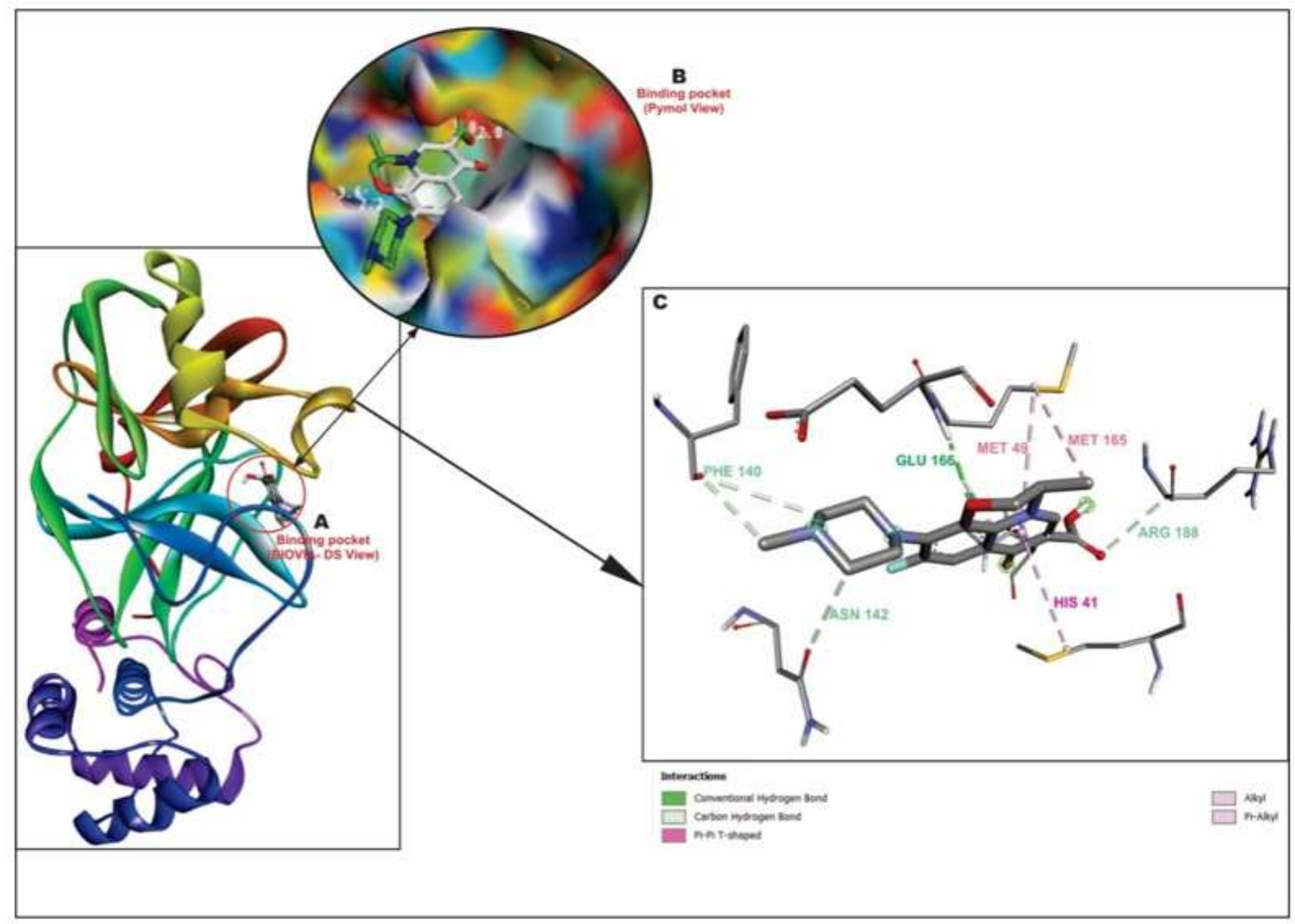

Figure 6

The binding pockets (A \& B) and binding mode (C) of C-1 (Tarivid) with amino acids in SARS-CoV-2Mpro (6LU7) 


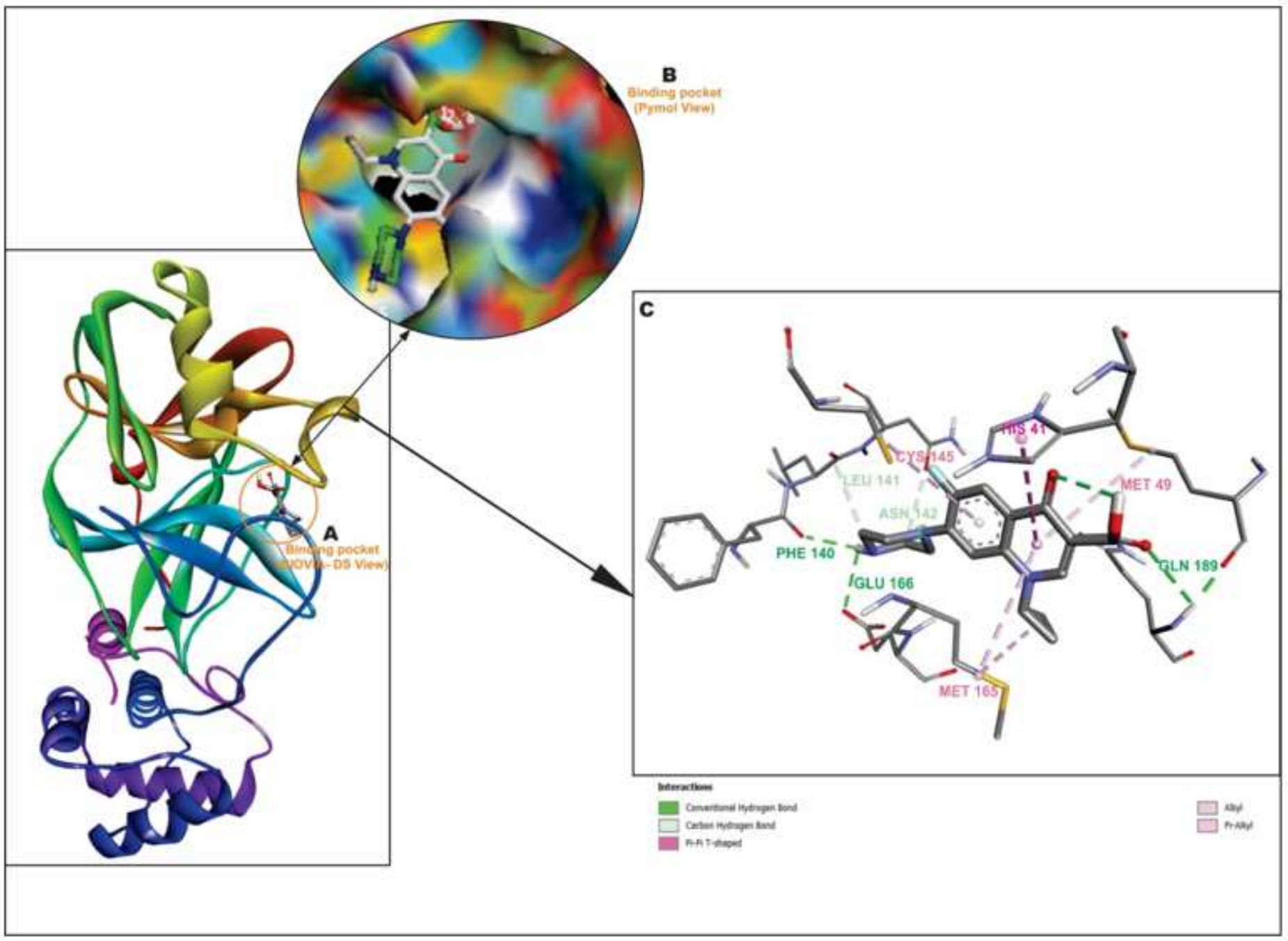

Figure 7

The binding pockets (A \& B) and binding mode (C) of C-2 (Ciprofloxacin) with amino acids in SARS-CoV-2 Mpro (6LU7) 


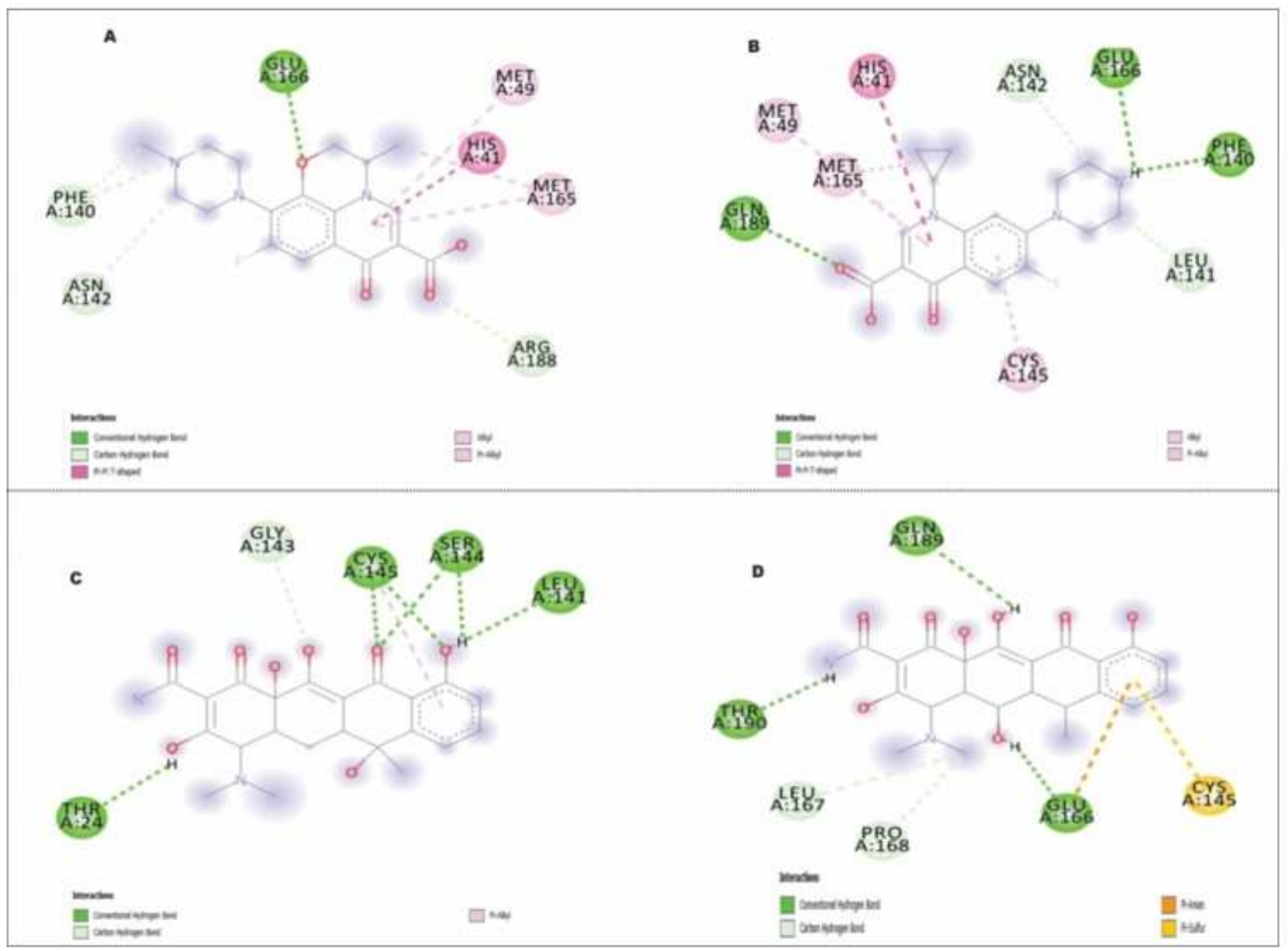

Figure 8

The molecular interactions of C-1 (Tarivid), C-2 (Ciprofloxacin), C-3 (Tetracycline) and C-4 (Doxycycline) with amino acids in SARS-CoV-2Mpro (6LU7)

\section{Supplementary Files}

This is a list of supplementary files associated with this preprint. Click to download.

- GraphicalAbstract.jpg 